\title{
Chemical variability in peralkaline magmas and magma reservoirs: insights from the Khaggiar lava flow, Pantelleria, Italy
}

\author{
David A. Neave ${ }^{1,2}$ (D)
}

Received: 9 December 2019 / Accepted: 23 March 2020 / Published online: 3 April 2020

(c) The Author(s) 2020

\begin{abstract}
Silicic volcanoes are increasingly understood to be underlain by crystal-rich and vertically extensive magma reservoirs within which disequilibrium is widespread. Observations from ignimbrite deposits demonstrate that silicic magma reservoirs are often compartmentalised and compositionally stratified. However, it is currently unclear whether the small (i.e., $<0.1 \mathrm{~km}^{3}$ dense rock equivalent) eruptions that dominate activity at many volcanoes, and peralkaline volcanoes in particular, are fed from similarly complex magma reservoirs as their larger counterparts. Here I report petrographic and geochemical observations from the products of a small peralkaline eruption on Pantelleria, Italy, with the aims of unravelling peralkaline magma assembly processes and evaluating the complexity of reservoirs feeding small silicic eruptions. Matrix glass and whole-rock compositions from the Khaggiar lava flow and Cuddia Randazzo pumice cone reveal that erupted magmas were assembled from at least three distinct magma types stored within a compartmentalised magma reservoir: trachytes, less-evolved pantellerites and evolved pantellerites. Chemical variability in the Khaggiar lava flow was created by at least three distinct processes: the accumulation of evolved macrocrysts into evolved pantellerites; the injection of trachytic magmas into less evolved pantellerites; and the accumulation of relatively primitive macrocrysts into trachytic magmas. Macrocryst textures indicate that both trachytic and pantelleritic domains of the magma reservoir experienced numerous recharge events prior to the one that ultimately triggered eruption. Overall, magmas forming the Khaggiar lava flow and Cuddia Randazzo pumice cone appear to have been assembled in analogous ways to those erupted in much larger events. My observations are in good agreement with those from other peralkaline volcanoes and confirm that magma mingling, crystal cannibalism and macrocryst entrainment are as ubiquitous in peralkaline systems as they are in their calc-alkaline counterparts.
\end{abstract}

Keywords Pantellerite $\cdot$ Crystal mush $\cdot$ Chemical variability $\cdot$ Magma mixing $\cdot$ Peralkaline

\section{Introduction}

\section{Chemical variability and magma reservoir complexity}

Many silicic volcanoes are underlain by complex magma reservoirs characterised by high average crystal contents (Marsh 1989, 2004; Hildreth 2004; Cooper and Kent 2014; Bachmann and Huber 2016; Cashman et al. 2017; Magee et al. 2018; Edmonds et al. 2019). Textural, chemical and isotopic disequilibria within and between erupted crystals demonstrate that individual eruptions often tap multiple thermochemically distinct domains within these reservoirs (e.g., Davidson and Tepley 1997; Davidson et al. 2007; Streck 2008; Cashman and Blundy 2013; Ellis et al. 2014). Zoned ignimbrite deposits, like those emplaced during the climactic calc-alkaline eruption of Mt. Mazama (Crater

2 Institut für Mineralogie, Leibniz Universität Hannover, Callinstraße 3, 30167 Hannover, Germany 
Lake), Oregon, USA, are typically thought to reflect the evacuation of chemically stratified magma bodies, providing insights into the nature of magma reservoir heterogeneity at depth (Hildreth 1981; Bacon and Druitt 1988; Druitt and Bacon 1989). Zoned ignimbrites with alkalic, tholeiitic and peralkaline affinities have also been recorded in intraplate (e.g., Gran Canaria, Canary Islands; Freundt and Schmincke 1992; Troll and Schmincke 2002), oceanic rift (e.g., Askja, Iceland; Sigurdsson and Sparks 1981) and continental rift (e.g., Pantelleria, Italy; Mahood and Hildreth, 1986) settings, respectively, suggesting that chemical variability and stratification are widespread features of silicic magma reservoirs. However, the lengthscales over which eruptible magmas maintain chemical variability at depth remain highly uncertain. Although major events like the climactic Mt. Mazama eruption ( $47 \pm 9 \mathrm{~km}^{3}$ dense rock equivalent; DRE) elegantly demonstrate how chemically distinct magmas can interact during large eruptions, much less is known about how magmas interact during the small (i.e., $<0.1 \mathrm{~km}^{3}$ ) that dominate eruptive activity at many volcanoes.

Chemical variability within the products of individual eruptions records information about vital processes such as mantle melting, fractional crystallisation, magma mixing, crystal entrainment and crustal assimilation (Fitton et al. 1983; Rhodes 1983; Rubin et al. 2001; Maclennan et al. 2003; Passmore et al. 2012; Neave et al. 2014; Halldórsson et al. 2018). Research on mafic systems has investigated chemical variability in lava flows spanning orders of magnitude in volume $\left(<0.01\right.$ to $>15 \mathrm{~km}^{3}$; Rubin et al. 2001; Maclennan et al. 2003; Passmore et al. 2012; Neave et al. 2014). In contrast, research on silicic systems has typically focussed on chemical variability in large-volume $\left(>5 \mathrm{~km}^{3}\right.$ DRE) pyroclastic deposits that facilitate systematic sampling throughout eruption chronologies (e.g., Wörner and Schmincke 1984; Freundt and Schmincke 1992). For example, chemical zonation within the $\sim 45 \mathrm{ka}$ Green Tuff of Pantelleria, Italy, which has been taken as evidence for a stably stratified magma reservoir beneath the island (Mahood 1984; Mahood and Hildreth 1986; White et al. 2009; Neave et al. 2012), and has been exploited to map the spatial and temporal evolution of ignimbrite emplacement during the eruption (Williams et al. 2013). In order to build holistic and unbiased models of magma reservoirs beneath silicic volcanoes, it is however essential to consider chemical variability in the products of small eruptions as well as large ones.

Determining the architecture and behaviour of magma reservoirs feeding small eruptions is particularly important for understanding peralkaline volcanoes that are often characterised by the emplacement of numerous small lava flows and pumice cones (e.g., Mahood and Hildreth 1986; Hutchison et al. 2016; Clarke et al. 2019). However, owing to the relative scarcity of peralkaline systems, our understanding of peralkaline magma reservoir processes is typically patchier than our understanding of calc-alkaline magma reservoir processes, notable exceptions aside (cf. White et al. 2009; Macdonald 2012; Iddon et al. 2018). This is despite peralkaline systems hosting major critical metal deposits (Wall 2014), having the potential to emit disproportionally large quantities of environmentally impacting sulphur (Scaillet and Macdonald 2006; Neave et al. 2012), and posing diverse volcanic hazards to those living around them, particularly in continental rift settings (Aspinall et al. 2011). This study, therefore, aims to deepen our understanding of peralkaline magmatism and bring it into closer alignment with our knowledge of more common expressions of magmatic activity.

Here I report petrographic and geochemical observations from the products of a small eruption of peralkaline rhyolite on Pantelleria, Italy. By using tools previously applied to the products of mafic eruptions, I present new insights into the pre- and syn-eruptive behaviour of the magma reservoir beneath Pantelleria (i.e., the pantescan magma reservoir), demonstrating key similarities with both peralkaline and calc-alkaline systems located elsewhere. Furthermore, by combining matrix glass and whole-rock analyses with contextualised microanalyses of crystal and enclave cargoes, I demonstrate that even very small $\left(<0.1 \mathrm{~km}^{3} \mathrm{DRE}\right)$ eruptions can involve numerous different magma batches, and that overlooking intra-eruption chemical variability can lead to magma reservoir complexity being considerably underestimated.

\section{Geological setting}

Pantelleria is located in the Strait of Sicily continental rift, approximately $100 \mathrm{~km}$ south of Sicily and $70 \mathrm{~km}$ east of Tunisia (Fig. 1; Civile et al. 2008). Volcanism has taken place on Pantelleria for over $300 \mathrm{ka}$ and is typically characterised by small, monogenetic eruptions punctuated by occasional ignimbrite-forming events (Civetta et al. 1984; Mahood and Hildreth 1986; Jordan et al. 2017). The most recent eruption took place a short distance northwest of the island in 1891. Although mafic magmatism occurs throughout the Strait of Sicily, Pantelleria is the only location where silicic magmatism is known to have developed (Civetta et al. 1998; Rotolo et al. 2006; White et al. 2009). Pantelleria is the type location for pantellerite, an iron-rich class of peralkaline rhyolite that forms the silicic end-member of bimodal magmatic suites in some ocean island and continental rift settings (Barberi et al. 1975; Mungall and Martin 1995; Civetta et al. 1998; Macdonald 2012; Hutchison et al. 2016; Iddon et al. 2018). Pantelleritic magmas are generally thought to be generated by the protracted fractional crystallisation of alkali basalt parents via trachytic intermediaries (White et al. 2009; Neave et al. 2012; Landi and Rotolo, 

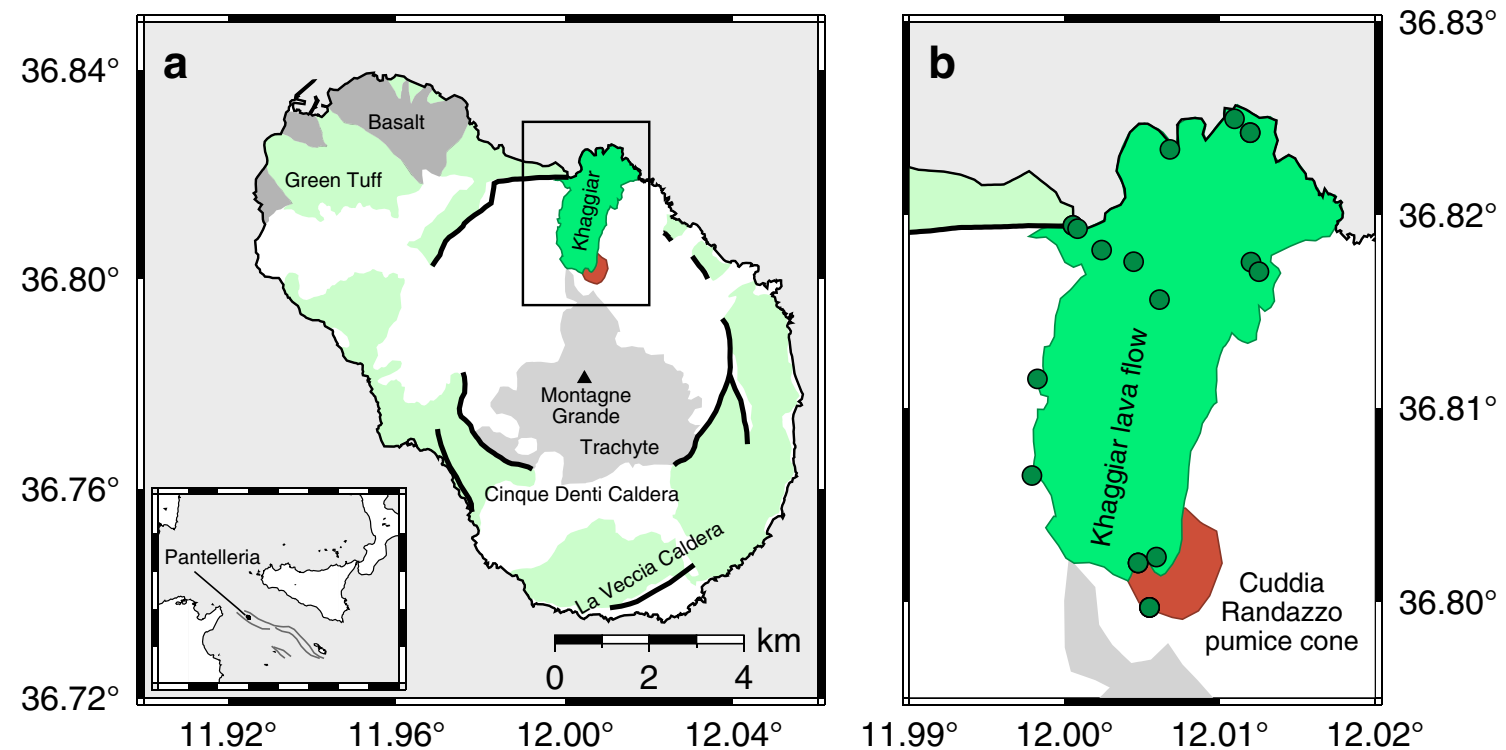

Fig. 1 Maps of Pantelleria showing sample locations. a Map showing the locations of the Khaggiar lava flow (bright green) and Cuddia Randazzo pumice cone (red) on the island of Pantelleria. Basaltic eruption products are shown in dark grey, and trachytic eruption products are shown in light grey. Deposits from the $\sim 45$ ka Green Tuff eruption are shown in pale green. Unshaded areas consist of pantelleritic eruption products. Prominent caldera ring faults are shown

2015; Gleeson et al. 2017). Pantellerites are of particular volcanological interest because their high alkali contents translate into melt viscosities that are two to three orders of magnitude lower than those of similarly evolved calc-alkaline melts (Di Genova et al. 2013), leading to complex eruption dynamics that remain subject to considerable uncertainty (Stevenson and Wilson 1997; Hughes et al. 2017).

The southeast of Pantelleria hosts a nested caldera complex (Mahood and Hildreth 1986). The youngest Cinque Dente caldera, which is possibly associated with the $\sim 45 \mathrm{ka}$ Green Tuff eruption, is partly filled by trachytes of the Montagna Grande-Monte Gibele system that were emplaced between $\sim 45$ and $\sim 30 \mathrm{ka}$ (Civetta et al. 1998). Subsequent activity (7-25 ka) in the southeast of the island has been characterised by monogenetic events of variable intensity that have produced silicic lava flows and geographically restricted fall deposits along caldera ring faults and other tectonic lineaments (Orsi et al. 1991; Rotolo et al. 2007; Scaillet et al. 2011). In contrast, activity in the northwest of Pantelleria has been characterised by the emplacement of lava flows, mafic scoria cones and silicic pumice conesthe most recent onshore mafic eruption took place at $\sim 10 \mathrm{ka}$ (Mahood and Hildreth 1986; Civetta et al. 1988).

The Khaggiar lava flow and Cuddia Randazzo pumice cone $\left(<0.1 \mathrm{~km}^{3}\right.$ DRE combined) are some of the youngest eruption products on Pantelleria $(\sim 8 \mathrm{ka}$; Scaillet et al. 2011). The Khaggiar lava flow is $\sim 3 \mathrm{~km}$ long and with thick black lines. Geological boundaries are marked according to Mahood and Hildreth (1986). The inset map shows the location of Pantelleria in the Strait of Sicily Rift between Italy and Tunisia. Rift bounding faults are shown as dark grey lines. b Detailed map showing individual sample locations from the Khaggiar lava flow and Cuddia Randazzo pumice cone. GPS coordinates of sample locations are provided in the Supplementary Dataset

stretches from its source at an endogenous dome within the northern flank of the Cuddia Randazzo pumice cone that formed immediately before lava effusion, to the sea at Punta Spadillo (Fig. 1). In a manner typical for silicic eruption centres on Pantelleria, deposits associated with Cuddia Randazzo contain a mixture of dense scoriae and highly vesicular pumice clasts (Rotolo et al. 2007; Hughes et al. 2017). In addition, they contain up to 20 vol. $\%$ trachytic enclaves that are variably rounded to amoeboid in form, and have been interpreted as evidence for mingling between trachytic and pantelleritic magmas immediately prior to eruption (Landi and Rotolo 2015). Trachytic enclaves are abundant throughout the Khaggiar lava flow (Mahood and Hildreth 1986; Perugini et al. 2002), suggesting that both the lava flow and the pumice cone were derived from the same magma body. Nonetheless, differences in chemistry between trachytic enclaves and their host pantellerites (whether lavas or pumices) make it possible to track the provenance of individual crystals (White et al. 2005; Landi and Rotolo 2015), and Prosperini et al. (2000) argued that trachytic enclaves carry a cargo of anorthoclase crystals accumulated from overlying pantellerites. The petrological diversity present in the Khaggiar lava flow and Cuddia Randazzo pumice cone, therefore, makes them an ideal target for investigating intra-eruption chemical variability and magma reservoir complexity in silicic, peralkaline systems. 


\section{Sample collection}

Samples were collected during fieldwork in September 2014 and consist of 13 lava samples from the Khaggiar lava flow, and four pumice samples, two enclave samples and one lithic sample from the Cuddia Randazzo pumice cone. Sampling locations are shown in Fig. 1. As far as possible, samples were collected from locations distributed across the lava flow and pumice cone. Further details about sampling locations and GPS coordinates are provided in the Supplementary Dataset. A total of 14 samples were selected for further investigation based on their relative freshness.

\section{Methods}

\section{Imaging}

Thin sections were investigated by optical and electron microscopy. Electron microscopy was performed using a JEOL JSM-7610F field emission gun scanning electron microscope (FEG-SEM) at the Institut für Mineralogie of the Leibniz Universität Hannover, Germany. Most imaging was performed at a working distance of $15 \mathrm{~mm}$ using an accelerating voltage of $15 \mathrm{kV}$.

\section{Electron probe microanalysis}

Glass and mineral compositions were determined by electron probe microanalysis (EPMA) at the Institut für Mineralogie of the Leibniz Universität Hannover, Germany, using a Cameca SX100 instrument. Silicon, Ti, Al, Fe, Mn, Mg, $\mathrm{Ca}, \mathrm{Na}, \mathrm{K}, \mathrm{P}, \mathrm{F}$ and $\mathrm{Cl}$ were measured in glasses with a beam size of $12 \mu \mathrm{m}$, an accelerating voltage of $15 \mathrm{kV}$ and a current of $10 \mathrm{nA}$. Silicon, Ti, Al, Fe, Mn, Mg, Ba, Ca, $\mathrm{Na}$ and $\mathrm{K}$ were measured in crystals with a beam size of $1 \mu \mathrm{m}$, an accelerating voltage of $15 \mathrm{kV}$ and a current of $15 \mathrm{nA}$. Elements were counted on peak for $20 \mathrm{~s}$, with the exceptions of $\mathrm{Si}$ and $\mathrm{Na}$ that were counted on peak for $10 \mathrm{~s}$ to minimise drift and migration, respectively. Background counting times were half on-peak counting times. The following standards were used for calibration: wollastonite ( $\mathrm{Si}$ and $\mathrm{Ca}$ ), $\mathrm{TiO}_{2}\left(\mathrm{Ti}\right.$ ), jadeite (Al), $\mathrm{Fe}_{2} \mathrm{O}_{3}$ (Fe in silicates) $\mathrm{Mn}_{3} \mathrm{O}_{4}(\mathrm{Mn})$, barite $(\mathrm{Ba}), \mathrm{MgO}(\mathrm{Mg})$, albite $(\mathrm{Na})$, orthoclase $(\mathrm{K})$, apatite $(\mathrm{P})$, fluorite $(\mathrm{F})$ and halite $(\mathrm{Cl})$. Data quality was monitored by analysing the following secondary standards: A-99 basaltic glass (NMNH 113498), Kakanui augite (NMNH 122142, using preferred values) and Lake County plagioclase (NMNH 115900) (Jarosewich et al. 1980). Glass $\mathrm{F}$ contents were corrected for interference from the $\mathrm{Fe} L_{\alpha}$ line using the approach of Zhang et al. (2015). Analytical uncertainties $(2 \sigma)$ were typically $<5 \%$ for major elements present at $\geq 1 \mathrm{wt} . \%$ and $<10 \%$ for minor elements present at $<1 \mathrm{wt}$. $\%$

\section{X-ray fluorescence}

$\mathrm{X}$-ray fluorescence (XRF) analyses were performed at the Department of Geology of the University of Leicester, UK, using a PANalytical Axios Advanced X-Ray Fluorescence spectrometer. The instrument runs with a $4 \mathrm{Kw}$ Rhodium $(\mathrm{Rh})$ anode end window super sharp ceramic technology $\mathrm{X}$-Ray tube. Major elements were analysed on fused glass beads prepared from ignited glass powders using a sampleto-flux ratio of 1:5 and a flux containing $80 \% \mathrm{Li}$ metaborate and $20 \% \mathrm{Li}$ tetraborate. Trace elements were analysed on $32 \mathrm{~mm}$ diameter pressed powder pellets produced by mixing $7 \mathrm{~g}$ of sample powder with $12-15$ drops of $7 \%$ PVA solution. Data quality was monitored though longitudinal analyses of an in-house granodiorite (BH-1) standard for major elements and USGS nepheline syenite (STM-1) standard for trace elements. Analytical uncertainties $(2 \sigma)$ were typically $<5 \%$ for major elements present at $\geq 1 \mathrm{wt} . \%$ and $<2 \%$ for trace elements present at $>50$ ppmw.

\section{Petrography and electron imaging}

Lava samples have porphyritic textures characterised by macrocrysts of, in order of decreasing abundance, alkali feldspar, clinopyroxene, aenigmatite and olivine in a glassy to microcrystalline groundmass. Macrocrysts are defined as crystals that are larger and texturally distinct from groundmass crystals (Thomson and Maclennan 2013). Trachytic enclaves are also present in some samples and are described below. Tabular alkali feldspar macrocrysts are 500-4000 $\mu \mathrm{m}$ in length (lengths are expressed as longaxis lengths throughout) and are readily distinguished from acicular groundmass crystals that are up to $100 \mu \mathrm{m}$ in length (Figs. 2a, 3a, b). Although alkali feldspar frequently occurs as individual macrocrysts, it also forms glomerocrysts. While some alkali feldspar macrocrysts are euhedral and faceted (Fig. 2a), others are subhedral with rounded crystal face intersections (Fig. 2b). Some also contain inclusions of clinopyroxene and olivine (Fig. 3a). Clinopyroxene macrocrysts are typically $100-1500 \mu \mathrm{m}$ in length and are readily distinguished from acicular groundmass crystals that reach up to $100 \mu \mathrm{m}$ in length by their equant and tabular habits. Although some clinopyroxenes are euhedral (Figs. 2c and 3b), highly resorbed anhedral forms are also present (Figs. 2b and 3b), with the most resorbed macrocrysts being found in samples containing trachytic enclaves. Some clinopyroxene macrocrysts contain apatite inclusions. Tabular aenigmatite macrocrysts are typically $200-800 \mu \mathrm{m}$ in length, subhedral to anhedral in form and frequently associated with clinopyroxene macrocrysts (Figs. 2a, c and $3 a)$. Rare equant olivine macrocrysts $200-500 \mu \mathrm{m}$ in length are typically the smallest macrocryst phase and sometimes 


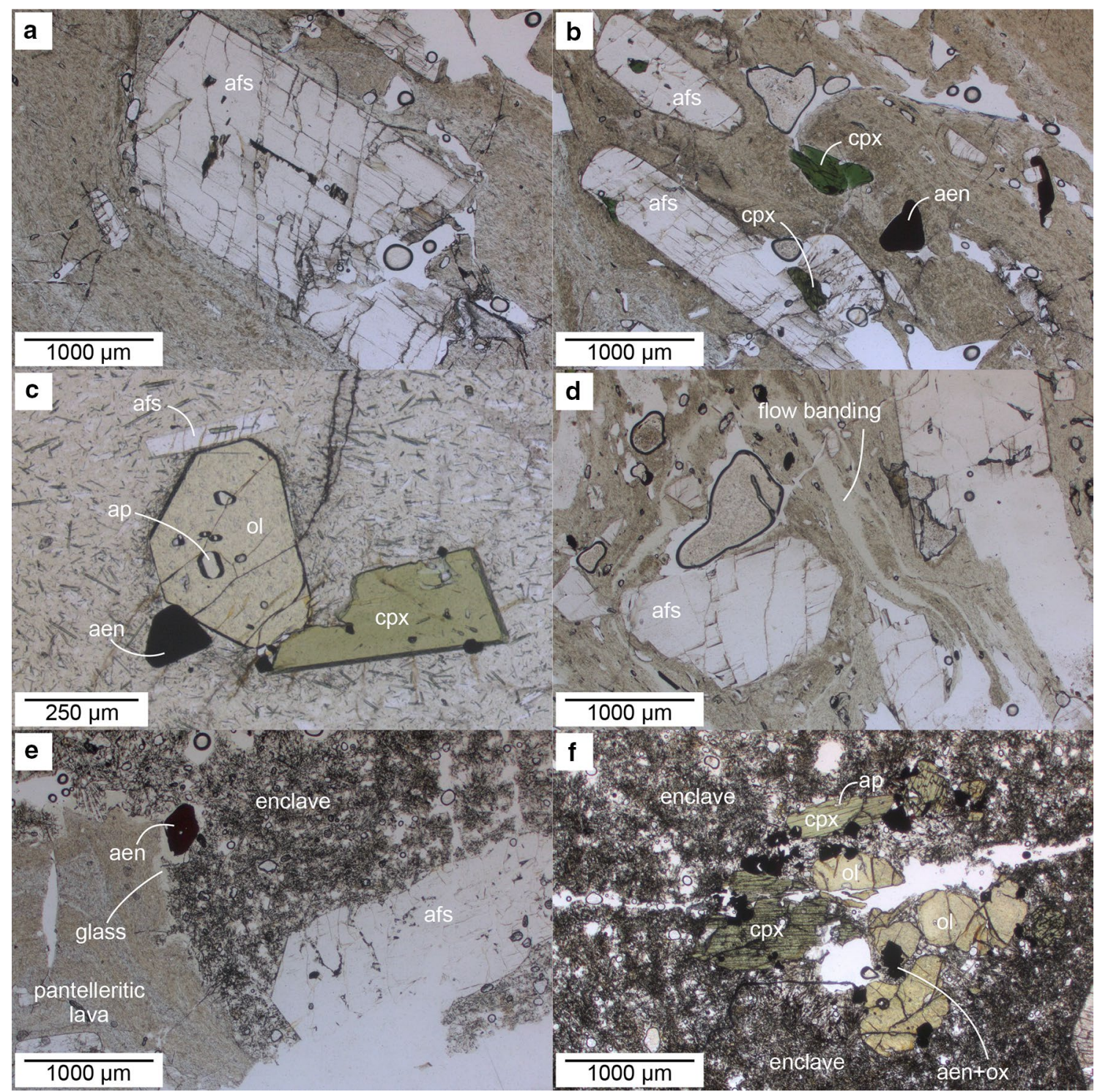

Fig. 2 Photomicrographs with plane polars of lava and enclave samples from the Khaggiar lava flow. a Euhedral alkali feldspar (afs) macrocryst in the microlite-bearing but largely glassy groundmass of lava sample 14PNL039A. Alkali feldspar is the dominant macrocryst in the Khaggiar lava flow. b Subhedral alkali feldspar macrocrysts with clinopyroxene (cpx) inclusions associated with anhedral clinopyroxene and aenigmatite (aen) macrocrysts in lava sample 14PNL039A. c Euhedral macrocrysts of alkali feldspar, clinopyroxene, aenigmatite and olivine (ol) in lava sample 14PNL036; apatite (ap) inclusions are also present in the olivine. Olivine is the rarest

host apatite inclusions (Fig. 2c). The groundmass is mostly glassy, though microlites of alkali feldspar and clinopyroxene are common. In some samples, microlites are aligned and appear to define flow banding (Fig. 2d). Variations in the back-scattered electron (BSE) intensity of the glass around some macrocrysts and within some macrocryst embayments reflect differences in the mean atomic number (i.e., mean $Z$ ) of the sample and indicate that matrix glasses are chemically macrocryst phase in the Khaggiar lava flow. d Variations in microlite abundance and alignment define flow banding in many lava samples like 14PNL050. e Boundaries between enclaves and their host lavas are defined by differences in groundmass crystallinity; enclaves have a largely crystalline groundmass while their host lava has a largely glassy groundmass like sample 14PNL039B. Large, euhedral alkali feldspar macrocrysts are common in enclaves. f Multiphase glomerocryst of clinopyroxene, aenigmatite, olivine, apatite and Fe-Ti oxide (ox) in an enclave within sample 14PNL039B

variable over lengthscales of 10 to $100 \mu \mathrm{m}$ (Fig. 3b; Supplementary Fig. 1).

Trachytic enclaves have porphyritic textures characterised by macrocrysts of, in order of decreasing abundance, alkali feldspar, clinopyroxene, olivine, aenigmatite, $\mathrm{Fe}-\mathrm{Ti}$ oxide and apatite in a largely crystalline groundmass. Indeed, enclaves are readily distinguished from their host lava by their crystalline groundmass (Fig. 2e). Tabular alkali 


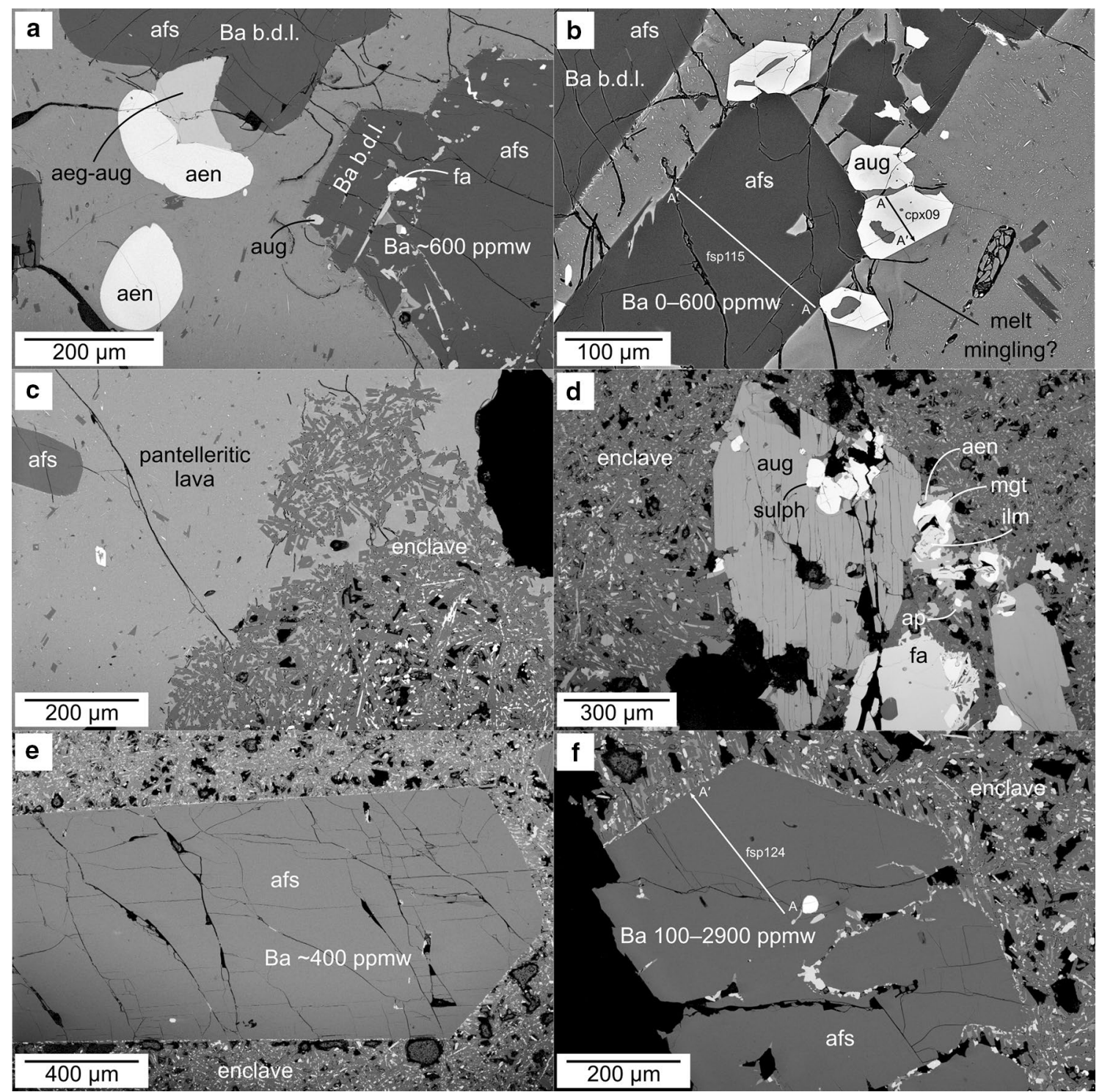

Fig. 3 BSE images of lava and enclave textures in sample 09PNL039B from the Khaggiar lava flow. a Alkali feldspar (afs) macrocryst textures vary greatly in the Khaggiar lava flow. Some alkali feldspars are euhedral like the example in the centre right, while others are subhedral and resorbed like the example in the top left. EPMA indicates that euhedral alkali feldspars are generally associated with higher Ba contents than subhedral alkali feldspars. The euhedral alkali feldspar shown here is also associated with inclusions of augite (aug) and fayalite (fa) while the subhedral alkali feldspar is associated with anhedral macrocrysts of aegirine-augite (aeg-aug) and aenigmatite (aen). b Some euhedral alkali feldspar macrocrysts are associated

feldspar macrocrysts are typically $1000-10000 \mu \mathrm{m}$ in length and thus larger on average than alkali feldspar macrocrysts in the host lava (Figs. 2e, 3e, f). Equant clinopyroxene and olivine macrocrysts are $400-1000 \mu \mathrm{m}$ in length and are frequently associated with all macrocryst phases apart from alkali feldspar (Figs. 2f and 3d). Clinopyroxene and olivine macrocrysts contain abundant melt, apatite, $\mathrm{Fe}-\mathrm{Ti}$ oxide and with euhedral augite macrocrysts and encased within films of highBSE intensity glass indicative of melt mingling processes. EPMA traverses presented in Figs. 7 and 9 are shown as white arrows. c Enclaves have a distinctly more crystalline groundmass textures than their lava hosts. d Multiphase glomerocrysts in enclaves are characterised by the complex intergrowth of augite, fayalite, aenigmatite, magnetite (mgt), ilmenite (ilm), apatite (ap) and sulphide (sulph). e and $\mathbf{f}$ Some euhedral alkali feldspars in enclave samples have modest and homogenous Ba contents (e), while others have highly variable Ba contents (f). An EPMA traverse presented in Fig. 7 is shown with a white arrow

sulphide inclusions (Fig. 3d). Tabular aenigmatites sometimes occur as individual macrocrysts up to $400 \mu \mathrm{m}$ in length (Fig. 2e), but are more frequently present in complex intergrowths with $\mathrm{Fe}-\mathrm{Ti}$ oxides, apatite and sulphide that are closely associated with clinopyroxene and olivine (Fig. 3d). Macrocrysts of apatite and $\mathrm{Fe}-\mathrm{Ti}$ oxide sometimes occur as individual macrocrysts but are mostly found intergrown with 
clinopyroxene, olivine and aenigmatite. The groundmass within trachytic enclaves is largely crystalline, consisting of alkali feldspar, clinopyroxene and aenigmatite crystals up to $50 \mu \mathrm{m}$ in length that are often organised in spherulitic arrangements. As described by Landi and Rotolo (2015), glass lines and fills many enclave-hosted vesicles (Supplementary Fig. 2).

\section{Analytical results}

\section{Matrix glass and whole-rock compositions}

\section{Major elements}

The major element systematics of matrix glasses and wholerock samples from the Khaggiar lava flow and Cuddia Randazzo pumice cone are summarised in Fig. 4. Variations in key major element oxide concentrations $\left[\mathrm{SiO}_{2}, \mathrm{Al}_{2} \mathrm{O}_{3}, \mathrm{FeO}\right.$ *
Fig. 4 Major element systematics of matrix glasses and wholerock samples from the Khaggiar lava flow and Cuddia Randazzo pumice cone. Key major element oxides concentrations are plotted as functions of sample peralkalinity [i.e., $(\mathrm{Na}+\mathrm{K}) / \mathrm{Al}$ on a molar basis]. Analyses are classified according to sample type. New data are presented alongside literature data from the Khaggiar lava flow and Cuddia Randazzo pumice cone reported by Neave et al. (2012) (N12) and Landi and Rotolo (2015) (LR15) and from other pantescan glasses reported by Civetta et al. (1998) (C98) and Neave et al. (2012). Error bars show $1 \sigma$ analytical uncertainties associated with X-ray fluorescence analysis; EPMA is associated with comparable uncertainties
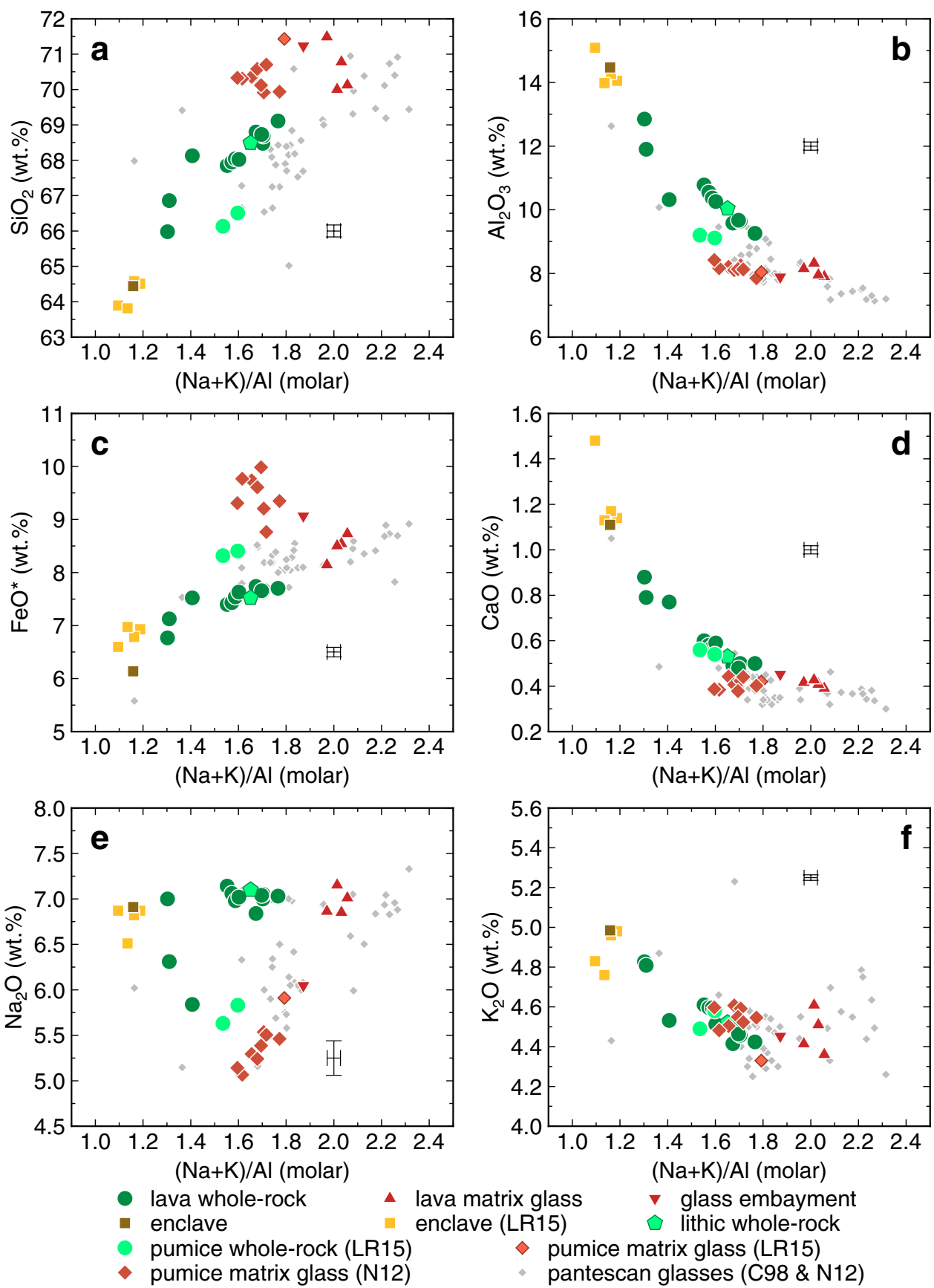


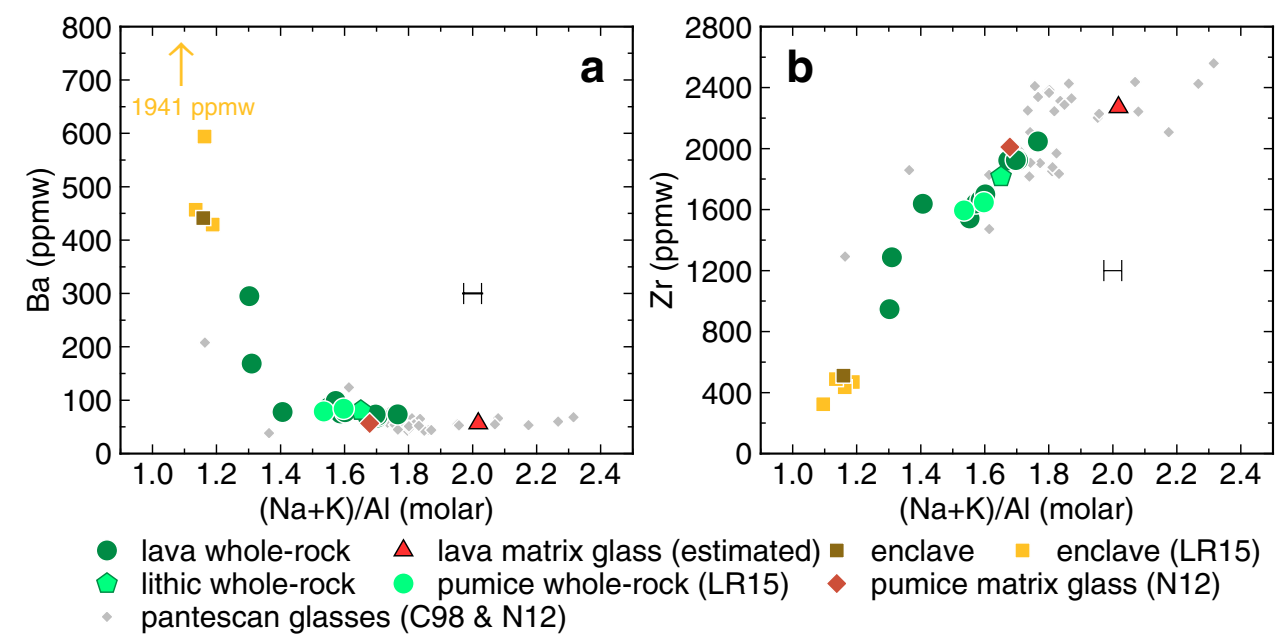

Fig. 5 Trace element systematics of matrix glasses and whole-rock samples from the Khaggiar lava flow and Cuddia Randazzo pumice cone. $\mathrm{Ba}(\mathbf{a})$ and $\mathrm{Zr}(\mathbf{b})$ concentrations are plotted functions of sample peralkalinity [i.e., $(\mathrm{Na}+\mathrm{K}) / \mathrm{Al}$ on a molar basis]. Analyses are classified according to sample type. New data are presented alongside lit-

(total $\mathrm{Fe}$ expressed as $\mathrm{FeO}$ ), $\mathrm{CaO}$ and $\left.\mathrm{Na}_{2} \mathrm{O}\right]$ are shown as functions of sample peralkalinity $[(\mathrm{Na}+\mathrm{K}) / \mathrm{Al}$ on a molar basis]. New data are plotted alongside literature data from the same eruption (Neave et al. 2012; Landi and Rotolo 2015) and from eruptions elsewhere on Pantelleria (Civetta et al. 1998; Neave et al. 2012). The systematics of minor elements $\left(\mathrm{TiO}_{2}, \mathrm{MnO}, \mathrm{MgO}, \mathrm{P}_{2} \mathrm{O}_{5}\right)$ are summarised in Supplementary Fig. 3 .

Matrix glass analyses were performed in three different contexts (Fig. 4): matrix glasses in the Khaggiar lava flow, matrix glasses in pumice clasts from the Cuddia Randazzo pumice cone and a glass embayment within an alkali feldspar macrocryst from the Khaggiar lava flow. Lava matrix glass compositions are rhyolitic and strongly peralkaline $\left[\mathrm{SiO}_{2}>70\right.$ wt.\%; $\left.(\mathrm{Na}+\mathrm{K}) / \mathrm{Al} \sim 2.0\right]$. They also lie towards the peralkaline end of reported pantescan glass compositions, indicating that the Khaggiar lava flow is comparatively differentiated for a pantescan rhyolite (Fig. 4; Civetta et al. 1998; Neave et al. 2012). Pumice matrix glass compositions reported by Neave et al. (2012) and Landi and Rotolo (2015) contain less $\mathrm{Na}_{2} \mathrm{O}$ than lava matrix glass compositions and are consequently less peralkaline $[(\mathrm{Na}+\mathrm{K}) / \mathrm{Al} \sim 1.7]$. They also contain more $\mathrm{SiO}_{2}$ and $\mathrm{FeO}^{*}$. However, their $\mathrm{Na}_{2} \mathrm{O}$, $\mathrm{CaO}$ and $\mathrm{K}_{2} \mathrm{O}$ contents are similar to those reported from other pantescan eruptions, indicating that differences in $\mathrm{Na}_{2} \mathrm{O}$ contents between lava and pumice matrix glass compositions are not the result of $\mathrm{Na}$ volatilisation (Fig. 4a, c). Moreover, the high totals (>98.5 wt.\%) of analyses reported by Neave et al. (2012) suggest that they were not compromised by devitrification or secondary hydration. The single glass embayment measured within an alkali feldspar erature data from the Khaggiar lava flow and Cuddia Randazzo pumice cone reported by Neave et al. (2012) (N12) and Landi and Rotolo (2015) (LR15) and from other pantescan glasses reported by Civetta et al. (1998) (C98) and Neave et al. (2012). Error bars show $1 \sigma$ analytical uncertainties associated with XRF analyses

macrocryst from the Khaggiar lava flow has a major element composition between those of lava and pumice matrix glasses $[(\mathrm{Na}+\mathrm{K}) / \mathrm{Al} \sim 1.9]$.

Whole-rock analyses were performed on three different sample types (Fig. 4): lava samples from the Khaggiar lava flow, an enclave sample from the Cuddia Randazzo pumice cone, and a lithic sample from the Cuddia Randazzo pumice cone. These are compared with two pumice samples and four enclave samples from the Cuddia Randazzo pumice cone measured by Landi and Rotolo (2015). Most lava samples and the single lithic sample define a main population in major element space that spans trachytic and rhyolitic compositions $\left[\mathrm{SiO}_{2} \sim 67.9-69.1 \mathrm{wt} . \%\right.$; $(\mathrm{Na}+\mathrm{K}) /$ $\mathrm{Al} \sim 1.5-1.8]$. Enclave samples are trachytic and only mildly peralkaline $\left[\mathrm{SiO}_{2} \sim 63.9-64.6\right.$ wt.\%; $\left.(\mathrm{Na}+\mathrm{K}) / \mathrm{Al} \sim 1.1-1.2\right]$, and thus represent the least differentiated samples considered here. One enclave sample is also notably enriched in $\mathrm{CaO}$ (Fig. 4d; Landi and Rotolo 2015). Three lava samples fall outside of the main population, especially in terms of their $\mathrm{Na}_{2} \mathrm{O}$ contents, and instead have compositions that lie between those of enclaves and matrix glasses from the Cuddia Randazzo pumice cone [(Na+K)/Al 1.3-1.4]. Finally, two pumice whole-rock compositions reported by Landi and Rotolo (2015) are compositionally closer to matrix glasses in pumice clasts from the Cuddia Randazzo pumice cone than most lava whole-rock compositions $[(\mathrm{Na}+\mathrm{K}) / \mathrm{Al} \sim 1.6]$.

\section{Trace elements}

Trace element systematics of matrix glasses and wholerock samples from the Khaggiar lava flow and Cuddia 
Randazzo pumice cone are summarised in Fig. 5. Ba and $\mathrm{Zr}$ were selected as typical trace elements because they were measured precisely and behave contrastingly during the differentiation of peralkaline magmas (Iddon et al. 2018): Ba is compatible in alkali feldspar, which leads to the rapid depletion of melt $\mathrm{Ba}$ contents during the crystallisation of trachytic magmas, whereas $\mathrm{Zr}$ is highly incompatible in all phases crystallising from peralkaline magmas, meaning that $\mathrm{Zr}$ provides an excellent index of magmatic differentiation. Although trace element data have been reported from the Cuddia Randazzo pumice cone (Neave et al. 2012), no matrix glass data are available for the Khaggiar lava flow. $\mathrm{I}$, therefore, predicted the mean $\mathrm{Ba}$ and $\mathrm{Zr}$ contents of lava matrix glasses from their mean peralkalinity $[(\mathrm{Na}+\mathrm{K}) /$ $\mathrm{Al} \sim 2.0$ ] by regressing literature data from highly peralkaline $[(\mathrm{Na}+\mathrm{K}) / \mathrm{Al}>1.8]$ pantescan glasses (Civetta et al. 1998; Neave et al. 2012).

Most lava samples, the single lithic sample, and pumice samples from Landi and Rotolo (2015) have low Ba contents (67-99 ppmw) that decrease slightly with increasing peralkalinity (Fig. 5a). Two low-peralkalinity lava samples with $[(\mathrm{Na}+\mathrm{K}) / \mathrm{Al}<1.4]$ have higher $\mathrm{Ba}$ contents $(169$ and 295 ppmw), and enclave samples have still higher Ba contents: most enclave samples contain 429-295 ppmw Ba, but one contains 1941 ppmw. The two Ba-rich lava samples also appear to lie on the same trend as enclave samples.

Almost all matrix glass and whole-rock compositions form a continuous trend in $\mathrm{Zr}$ that extends from $\sim 400 \mathrm{ppmw}$ in enclave samples to $2000 \mathrm{ppmw}$ in lava samples; lava matrix glass $\mathrm{Zr}$ contents are estimated to be slightly higher at $\sim 2300$ ppmw. Only two moderately peralkaline lava samples $[(\mathrm{Na}+\mathrm{K}) / \mathrm{Al} \sim 1.3-1.4]$ fall slightly above the main trend. Both new and literature data for the Khaggiar lava flow and Cuddia Randazzo pumice cone have $\mathrm{Zr}$ contents consistent with those reported for other pantescan glasses.

\section{Macrocryst compositions}

Mean compositions of lava-hosted alkali feldspars plot largely within the anorthoclase field, consistent with crystallisation at the albite $\left(\mathrm{Ab}, \mathrm{NaAlSi}_{3} \mathrm{O}_{8}\right)$-orthoclase (Or, $\mathrm{KAlSi}_{3} \mathrm{O}_{8}$ ) minimum $\sim \mathrm{Or}_{35}$, where $\mathrm{Or}=$ molar $\mathrm{K} /$ $(\mathrm{Ca}+\mathrm{Na}+\mathrm{K}) \times 100$ (Fig. 6a; Tuttle and Bowen 1958; Macdonald et al. 2011; Wilke et al. 2017); only three macrocrysts plot within the sanidine field $\left(\sim \mathrm{Or}_{37-40}\right)$. Lava-hosted alkali feldspars also contain very little to no anorthite (An, $\mathrm{CaAl}_{2} \mathrm{Si}_{2} \mathrm{O}_{8}$ ) component: An contents [where $\mathrm{An}=$ molar $\mathrm{Ca} /(\mathrm{Ca}+\mathrm{Na}+\mathrm{K}) \times 100]$ vary from $\sim \mathrm{An}_{0}$ to $\sim \mathrm{An}_{1}$ (referred to as An-free in subsequent discussions). Mean compositions of enclave-hosted alkali feldspars also plot within the anorthoclase field. Although enclave-hosted alkali feldspar compositions overlap with those from lava-hosted alkali feldspars, they also extend to lower Or contents $\left(\mathrm{Or}_{24}\right)$ and higher An contents $\left(\sim \mathrm{An}_{4}\right.$; referred to as An-bearing in subsequent discussions). However, averaging across whole macrocrysts causes some compositions to fall off the pantescan trend defined by literature data (White et al. 2009; Neave et al. 2012; Liszewska et al. 2018). This is because some mean compositions reflect mixtures of An-free and An-bearing compositions with pantelleritic and trachytic affinities, respectively. Alkali feldspar An contents correlate positively with their Ba contents (Fig. 6b), with Ba

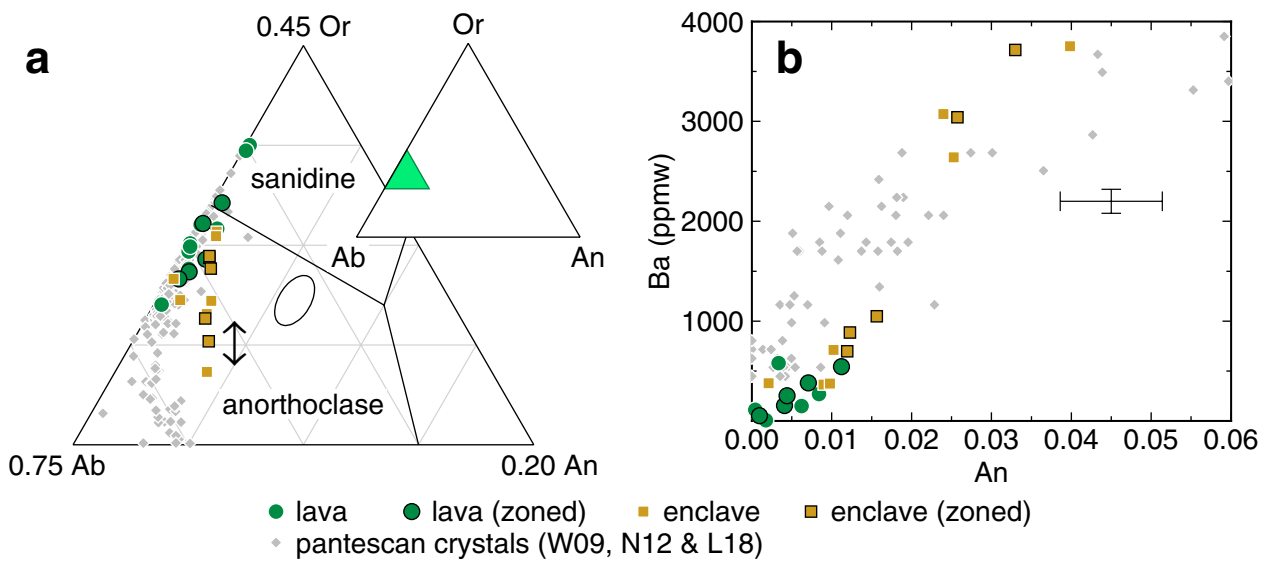

Fig. 6 Mean compositions of alkali feldspar macrocrysts in lava and enclave samples from the Khaggiar lava flow. New data are presented alongside literature data from diverse pantescan eruption products reported by White et al. (2009) (W09), Neave et al. (2012) (N12) and Liszewska et al. (2018) (L18). a Alkali feldspar compositions projected onto the albite-orthoclase-anorthite $(\mathrm{Ab}-\mathrm{Or}-\mathrm{An})$ ternary. Lavahosted macrocrysts show a distinct, An-free trend with respect to An-bearing enclave-hosted macrocrysts. Some enclave-hosted macro- cryst composition plot off the trend defined by literature data because their mean compositions reflect mixtures of An-free and An-bearing compositions with pantelleritic and trachytic affinities, respectively (mixing trend shown by arrow). Outlined symbols show the mean compositions of zoned macrocrysts. The error ellipse represents the propagation of $1 \sigma$ analytical uncertainties associated with EPMA. b variations of alkali feldspar An and Ba contents. Error bars show $1 \sigma$ analytical uncertainties associated with EPMA 
ranging from below the EPMA detection limit ( $<100 \mathrm{ppmw}$ ) at $\sim \mathrm{An}_{0}$ to $\sim 650 \mathrm{ppmw}$ at $\mathrm{An}_{1}$ in lava-hosted alkali feldspars, and from $\sim 400 \mathrm{ppmw}$ at $\sim \mathrm{An}_{1}$ to $\sim 3800 \mathrm{ppmw}$ at $\sim \mathrm{An}_{4}$ in enclave-hosted macrocrysts. These variations are consistent with those reported from other pantescan alkali feldspars (Liszewska et al. 2018).

Some alkali feldspars are compositionally zoned (Fig. 7). Although variations in alkali feldspar Or, An and Ba contents rarely exceed analytical uncertainty in lava-hosted macrocrysts (Fig. 7a), they often do in enclave-hosted macrocrysts (Fig. 7b). Or and An contents correlate negatively and, although high Ba contents are always associated with high An contents, high An contents are not always associated with high Ba contents. Overall, the nature and extent of compositional zoning in alkali feldspars varies greatly. Although a systematic characterisation of alkali feldspar zonation is beyond the scope of this study, the observations presented here demonstrate the degree of microscale complexity in the Khaggiar lava flow's macrocryst and enclave cargoes.

Mean compositions of lava-hosted clinopyroxenes range from augite to aegirine-augite and lie close to the hedenbergite $\left(\mathrm{Hd}, \mathrm{CaFe}^{2+} \mathrm{Si}_{2} \mathrm{O}_{6}\right)$ apex of the pyroxene quadrilateral (Fig. 8a), overlapping with some but not all compositions reported from evolved pantescan rocks (White et al. 2009; Neave et al. 2012; Liszewska et al. 2018). Most lava-hosted clinopyroxenes are Fe-rich, with $\mathrm{Mg \#}$ values of 0.05-0.10 (Fig. $8 \mathrm{~b}$ ), where $\mathrm{Mg} \#=$ molar $\mathrm{Mg} /\left(\mathrm{Mg}+\mathrm{Fe}^{*}\right)$ and $\mathrm{Fe}^{*}$ is total $\mathrm{Fe}$. Four clinopyroxenes (aegirine-augites) are enriched in aegirine component $\left(\mathrm{Ae}, \mathrm{NaFe}^{3+} \mathrm{Si}_{2} \mathrm{O}_{6}\right)$ at the expense of quadrilateral components (Fig. 8c). Zoned lava-hosted clinopyroxene macrocrysts are on average poorer in $\mathrm{Fe}$ than their unzoned counterparts, with mean Mg\# values of $0.10-0.15$. However, these lower mean $\mathrm{Fe}$ contents primarily reflect a compositional dichotomy between Fe-rich rims $(\mathrm{Mg} \# \leq 0.1)$ and $\mathrm{Fe}$-poor cores $(\mathrm{Mg} \#>0.2)$ that is also reflected in correlated variations in Ae component (Figs. 3a and 9). Clinopyroxene inclusions found within some lava-hosted alkali feldspars have very similar compositions to the mean compositions of zoned lava-hosted clinopyroxenes (i.e., Mg\# 0.10-0.15; Figs. 3a and 8b). Enclave-hosted clinopyroxenes are augitic and notably poorer in Fe than their lavahosted counterparts (Mg\# 0.22-0.24; Fig. 8b). They are also poor in Ae component and similar in composition to the cores of zoned lava-hosted clinopyroxenes (Figs. 8c and 9).

Mean compositions of lava-hosted aenigmatites are distinguished from those of enclave-hosted aenigmatites by their higher $\mathrm{Si}+\mathrm{Na}$ contents and lower $\mathrm{Al}+\mathrm{Ca}$ contents (Fig. 10a) that reflect compositional differences in their carrier magmas: pantelleritic lavas are Si-rich and trachytic enclaves are Si-poor (Figs. 4). The presence of aenigmatite in trachytic enclaves is however somewhat surprising given that aenigmatite is typically stable in only strongly peralkaline magmas (Macdonald et al. 2011). Indeed, Landi and Rotolo (2015) did not report aenigmatite in their enclave samples from the Cuddia Randazzo pumice cone. Nevertheless, comparisons with literature data indicate that the aenigmatites I describe here probably reflect the limit of pantescan aenigmatite stability (Fig. 10a; Mahood and Stimac 1990; White et al. 2009; Neave et al. 2012; Liszewska et al. 2018); enclave-hosted aenigmatites define the low$\mathrm{Si}+\mathrm{Na}$, high- $\mathrm{Al}+\mathrm{Ca}$ bound of pantescan compositions but do not extend much beyond published values.

All measured olivines are rich in fayalite $\left(\mathrm{Fa}, \mathrm{Fe}_{2} \mathrm{SiO}_{4}\right)$ and tephroite (Tp, $\mathrm{Mn}_{2} \mathrm{SiO}_{4}$ ) components (Fig. 10b, c). The single lava-hosted olivine measured is highly fayalitic $\left(\sim \mathrm{Fa}_{93}\right)$ and appreciably tephroitic $\left(\sim \mathrm{Tp}_{5}\right)$, but comparable to
Fig. 7 Compositions of zoned alkali feldspar macrocrysts hosted in lava (a) and enclave (b) samples summarised in terms of their Or, An and Ca contents. Locations of EPMA traverses are shown in Figs. 3b, f. Error bars show $1 \sigma$ analytical uncertainties associated with EPMA

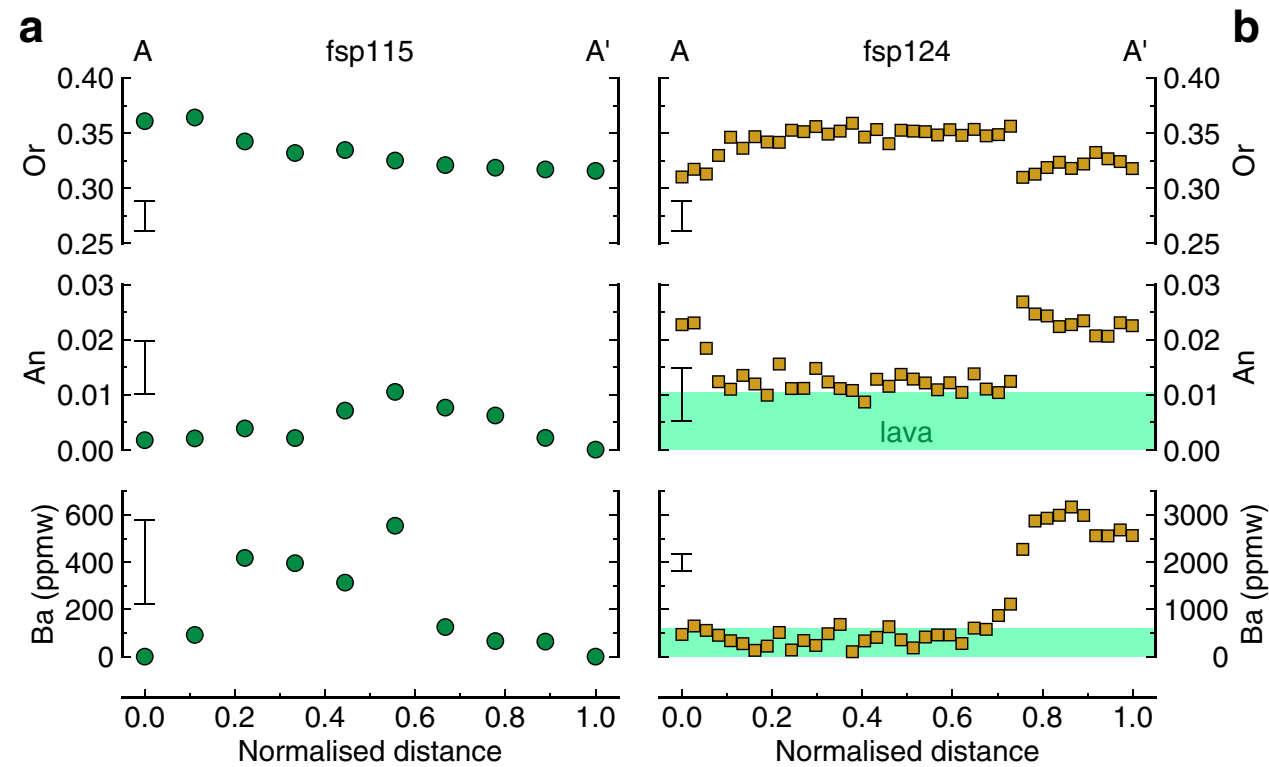



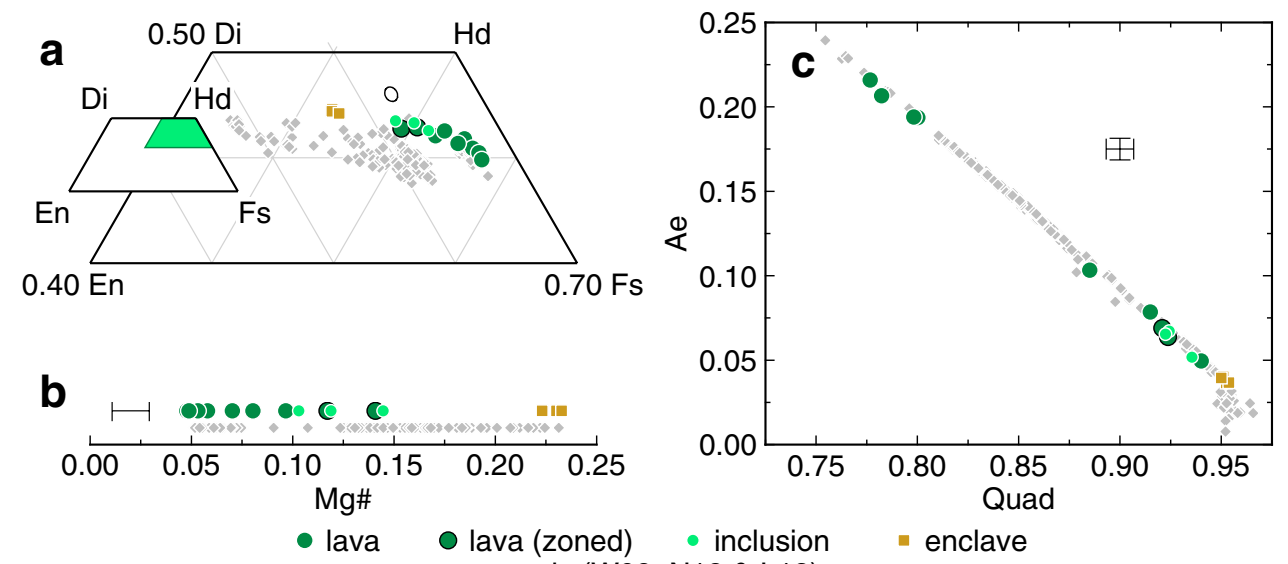

b

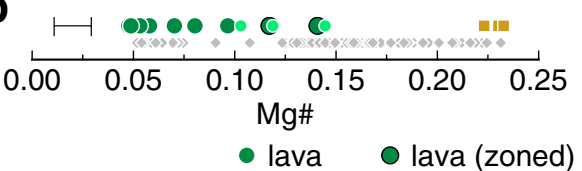

Fig. 8 Mean compositions of clinopyroxene macrocrysts and alkali feldspar-hosted clinopyroxene inclusions in lava and enclave samples from the Khaggiar lava flow. New data are presented alongside literature data from diverse pantescan eruption products reported by White et al. (2009) (W09), Neave et al. (2012) (N12) and Liszewska et al. (2018) (L18). a Clinopyroxene compositions projected onto the pyroxene quadrilateral (diopside, Di; hedenbergite, Hd; enstatite, En; ferrosillite, Fs). Outlined symbols show the mean compositions

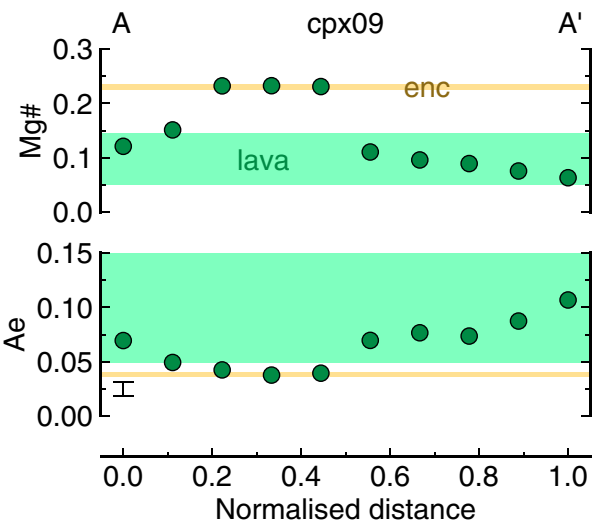

Fig. 9 Composition of a zoned lava-hosted clinopyroxene macrocryst summarised in terms of its $\mathrm{Mg} \#$ and Ar content. The location of the EPMA traverses is shown in Fig. 3b. Shaded bars show average lavaand enclave (enc)-hosted clinopyroxene compositions. Error bars show $1 \sigma$ analytical uncertainties associated with EPMA

compositions reported in the literature from other pantescan eruptions (White et al. 2009; Neave et al. 2012; Liszewska et al. 2018). In contrast, enclave-hosted olivines are slightly less fayalitic $\left(\sim \mathrm{Fa}_{86}\right)$ but slightly more tephroitic $\left(\sim \mathrm{Tp}_{7}\right)$. Olivine inclusions found within some lava-hosted alkali feldspars are more fayalitic than enclave-hosted olivines but less fayalitic than the single lava-hosted olivine measured $\left(\sim \mathrm{Fa}_{87-89} ;\right.$ Fig. 10b). Although previous studies reported $\mathrm{Fe}-\mathrm{Ti}$ oxide (ilmenite) and apatite in the Khaggiar lava flow (White et al. 2009), neither were observed as macrocryst phases in the lava samples investigated here. Fe-Ti oxide of zoned macrocrysts. The error ellipse represents the propagation of $1 \sigma$ analytical uncertainties associated with EPMA. b Clinopyrox-

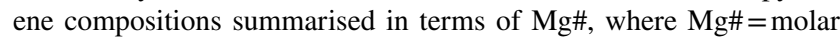
$\mathrm{Mg} /\left(\mathrm{Mg}+\mathrm{Fe}^{*}\right)$ and $\mathrm{Fe}^{*}$ is total $\mathrm{Fe}$. The error bar shows $1 \sigma$ analytical uncertainties associated with EPMA. c Clinopyroxene compositions summarised in terms of aegirine component (Ae) and the sum of quadrilateral component (Quad, i.e., $\mathrm{Di}+\mathrm{Hd}+\mathrm{En}+\mathrm{Fs}$ ) contents. Error bars show $1 \sigma$ analytical uncertainties associated with EPMA

(ilmenite and magnetite) and apatite nevertheless occur in trachytic enclaves (Figs. $2 \mathrm{f}$ and $3 \mathrm{~d}$ ), with apatite also occurring as inclusions within some lava-hosted clinopyroxene and olivine macrocrysts (Fig. 2c). Calculations with the two-oxide oxybarometer of Andersen and Lindsley (1988) suggest that the trachyte enclave shown in Figs. $2 \mathrm{f}$ and $3 \mathrm{~d}$ last equilibrated at a temperature $\sim 910{ }^{\circ} \mathrm{C}$ and an oxygen fugacity $\left(f_{\mathrm{O}_{2}}\right) 1.2 \log$ units below the quartz-fayalite-magnetite buffer. Although these values are in good agreement with published values (White et al. 2005), the large uncertainties associated with temperature and $f_{\mathrm{O}_{2}}$ estimates from individual oxide pairs $\left(\geq 50^{\circ} \mathrm{C}\right.$ and $\geq 0.4 \log$ units, respectively) imply imperfect equilibrium and these results should be treated with caution.

\section{Discussion}

\section{Chemical variability in the Khaggiar lava flow}

Signal-to-noise ratios $\left[\sigma_{\mathrm{t}} / \sigma_{\mathrm{r}}\right.$, where $\sigma_{\mathrm{t}}$ is the true variability estimated from the observed variability $\left(\sigma_{0}\right)$ and analytical uncertainty $\left(\sigma_{\mathrm{r}}\right)$ using the relationship $\sigma_{\mathrm{t}}^{2}=\sigma_{\mathrm{o}}^{2}-\sigma_{\mathrm{r}}^{2}$ ] allow the true, geological variability in geochemical datasets to be distinguished from the variability associated with analytical uncertainty (Maclennan et al. 2003). Signal-to-noise ratios estimated for whole-rock samples from the Khaggiar lava flow are provided in Table 1. Evaluating the significance of $\sigma_{\mathrm{t}} / \sigma_{\mathrm{r}}$ values with the $\chi^{2}$ distribution demonstrates that $\mathrm{SiO}_{2}$, $\mathrm{Al}_{2} \mathrm{O}_{3}, \mathrm{FeO}^{*}$ and $\mathrm{CaO}$ vary significantly at $p<0.05$ (i.e., 


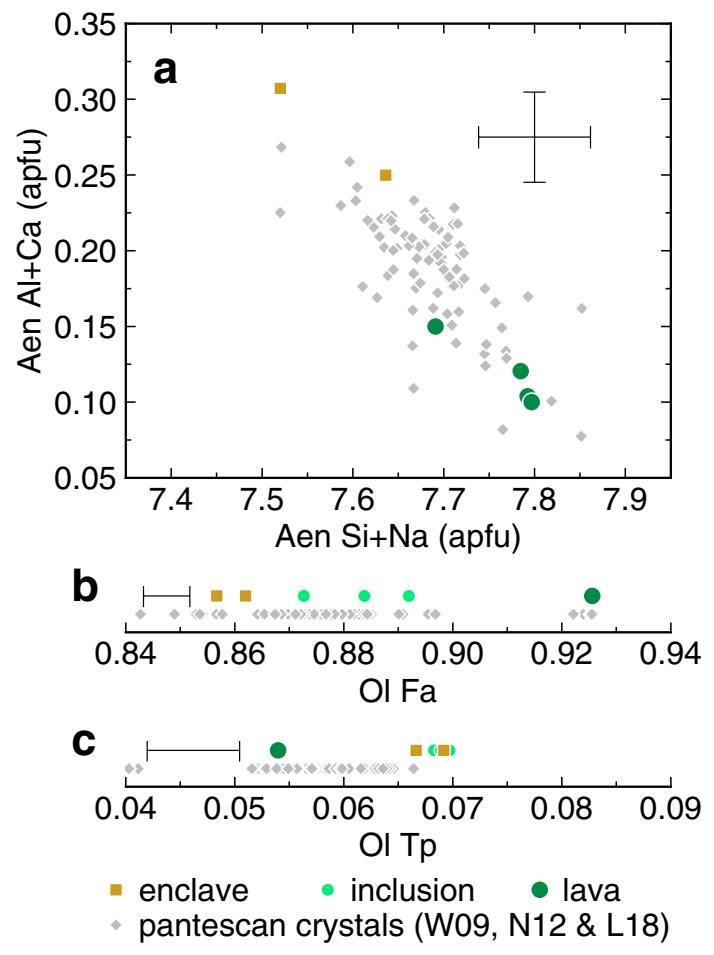

Fig. 10 Compositions of aenigmatite macrocrysts, olivine macrocrysts and alkali feldspar-hosted olivine inclusions in lava and enclave samples from the Khaggiar lava flow. Error bars show $1 \sigma$ analytical uncertainties associated with EPMA. New data are presented alongside literature data from diverse pantescan eruption products reported by White et al. (2009) (W09), Neave et al. (2012) (N12) and Liszewska et al. (2018) (L18). a Aenigmatite compositions summarised in terms of the $\mathrm{Si}+\mathrm{Na}-\mathrm{Al}+\mathrm{Ca}$ exchange (e.g., Macdonald et al. 2011). $\mathbf{b}$, c Olivine compositions summarised in terms of $\mathbf{b}$ fayalite $(\mathrm{Fa})$ and c tephroite (Tp) contents

$\sigma_{\mathrm{t}} / \sigma_{\mathrm{r}}>1.83$ ) while $\mathrm{Na}_{2} \mathrm{O}$ and $\mathrm{K}_{2} \mathrm{O}$ do not (i.e., $\sigma_{\mathrm{t}} / \sigma_{\mathrm{r}}<1.83$ ). Precisely determined trace elements vary with high degrees of significance $(p<<0.01)$, and $\sigma_{\mathrm{t}} / \sigma_{\mathrm{r}}$ exceeds 100 for both $\mathrm{Ba}$ and $\mathrm{Zr}$. Whole-rock samples from the Khaggiar lava flow, therefore, show significant intra-flow chemical variability that approaches the magnitude of that described from the much more voluminous $\sim 45 \mathrm{ka}$ Green Tuff (Williams et al. 2013; Liszewska et al. 2018).

A cross-correlation matrix for whole-rock data from the Khaggiar lava flow (including the lithic sample from the Cuddia Randazzo pumice cone) is provided in Supplementary Fig. 4 and constitutes a powerful summary of highly correlated chemical variability. For example, $\mathrm{SiO}_{2}$ correlates positively with $\mathrm{MnO}(r \sim 0.97), \mathrm{Zr}(r \sim 0.96)$, rare earth elements (REEs; $r \sim 0.90-0.94)$ and $\mathrm{FeO}^{*}(r \sim 0.64)$, but negatively with $\mathrm{CaO}(r \sim-0.90), \mathrm{Al}_{2} \mathrm{O}_{3}(r \sim-0.88)$, $\mathrm{K}_{2} \mathrm{O}(r \sim-0.85), \mathrm{TiO}_{2}(r \sim-0.82), \mathrm{MgO}(r \sim-0.73)$ and $\mathrm{Ba}(r \sim-0.68) . \mathrm{Na}_{2} \mathrm{O}$ does not correlate strongly with any elements and only weak negative correlations with $\mathrm{FeO}^{*}$ $(r \sim-0.39)$ and $\mathrm{MgO}(r \sim-0.30)$ can be resolved.
Table 1 Geochemical variability in whole-rock major and trace elements measured by XRF

\begin{tabular}{|c|c|c|c|c|c|}
\hline & $\bar{x}$ & $\sigma_{\mathrm{o}}$ & $\sigma_{\mathrm{r}}$ & $\sigma_{\mathrm{t}}$ & $\sigma_{\mathrm{t}} / \sigma_{\mathrm{r}}$ \\
\hline $\mathrm{SiO}_{2}$ (wt.\%) & 68.09 & 0.85 & 0.17 & 0.83 & 4.81 \\
\hline $\mathrm{TiO}_{2}$ & 0.47 & 0.04 & 0.00 & 0.04 & 10.17 \\
\hline $\mathrm{Al}_{2} \mathrm{O}_{3}$ & 10.37 & 1.01 & 0.13 & 1.00 & 7.57 \\
\hline $\mathrm{FeO}^{*}$ & 8.32 & 0.30 & 0.09 & 0.29 & 3.13 \\
\hline $\mathrm{MnO}$ & 0.31 & 0.01 & 0.01 & - & - \\
\hline $\mathrm{MgO}$ & 0.10 & 0.07 & 0.00 & 0.07 & 23.69 \\
\hline $\mathrm{CaO}$ & 0.60 & 0.13 & 0.02 & 0.13 & 7.21 \\
\hline $\mathrm{Na}_{2} \mathrm{O}$ & 6.88 & 0.38 & 0.19 & 0.32 & 1.67 \\
\hline $\mathrm{K}_{2} \mathrm{O}$ & 4.56 & 0.13 & 0.15 & - & - \\
\hline $\mathrm{P}_{2} \mathrm{O}_{5}$ & 0.04 & 0.01 & 0.00 & 0.01 & 1.53 \\
\hline $\mathrm{Ba}(\mathrm{ppmw})$ & 101 & 64 & 0.6 & 64 & 100 \\
\hline $\mathrm{Ce}$ & 363 & 57 & 1.8 & 57 & 32 \\
\hline $\mathrm{Ga}$ & 40 & 1 & 0.9 & 0 & 1 \\
\hline $\mathrm{La}$ & 180 & 29 & 0.8 & 29 & 37 \\
\hline $\mathrm{Nb}$ & 355 & 60 & 0.3 & 60 & 181 \\
\hline $\mathrm{Nd}$ & 145 & 21 & 0.9 & 21 & 23 \\
\hline $\mathrm{Rb}$ & 170 & 26 & 0.3 & 26 & 98 \\
\hline $\mathrm{Y}$ & 156 & 25 & 1.0 & 25 & 26 \\
\hline $\mathrm{Zn}$ & 345 & 51 & 1.1 & 51 & 46 \\
\hline $\mathrm{Zr}$ & 1691 & 304 & 2.1 & 304 & 143 \\
\hline
\end{tabular}

Bold indicates where signal-to-noise exceeds the threshold for statistical significance at $p<0.05(1.83)$

$\bar{x}$, mean of samples; $\sigma_{\mathrm{o}}$, observed standard deviation from the mean of samples; $\sigma_{\mathrm{r}}$, repeat standard deviation based on multiple repeat analyses; $\sigma_{\mathrm{t}}$, true standard deviation; $\sigma_{\mathrm{t}} / \sigma_{\mathrm{r}}$, signal-to-noise ratio (e.g., Maclennan et al. 2003)

Principal component analysis (PCA) allows entwined signatures of chemical variability to be identified and disentangled; the application of PCA to geological problems is discussed in detail by Allègre et al. (1995), Slater et al. (2001) and Neave et al. (2012). Elemental weightings for the first three principal components of whole-rock data from the Khaggiar lava flow are shown in Fig. 11. The first principal component, which accounts for $85.3 \%$ of the total variance, is defined by weightings corresponding to much the correlated variability described above (i.e., $\mathrm{SiO}_{2}$, REEs and $\mathrm{FeO} *$ versus $\mathrm{CaO}, \mathrm{A}_{2} \mathrm{O}_{3}, \mathrm{~K}_{2} \mathrm{O}$ and $\mathrm{Ba}$ ). The second principal component, which accounts for $7.5 \%$ of the total variance, is defined by a strongly negative weighting for $\mathrm{Na}_{2} \mathrm{O}$ and weak positive weightings for $\mathrm{FeO}^{*}$ and $\mathrm{MgO}$, which mirrors $\mathrm{Na}_{2} \mathrm{O}$ 's correlation pattern (Supplementary Fig. 4). The third principal component, which accounts for $4.3 \%$ of the total variance, is defined by positive weightings for $\mathrm{MgO}, \mathrm{P}_{2} \mathrm{O}_{5}$, $\mathrm{Ba}, \mathrm{TiO}_{2}$ and $\mathrm{Na}_{2} \mathrm{O}$ and negative weightings for $\mathrm{K}_{2} \mathrm{O}$ and to a lesser extent $\mathrm{MnO}$ and $\mathrm{Al}_{2} \mathrm{O}_{3}$. Overall, the first three principal components account for $>97 \%$ of the total variance in the Khaggiar lava flow, indicating that three distinct processes account for most of the variability observed. 


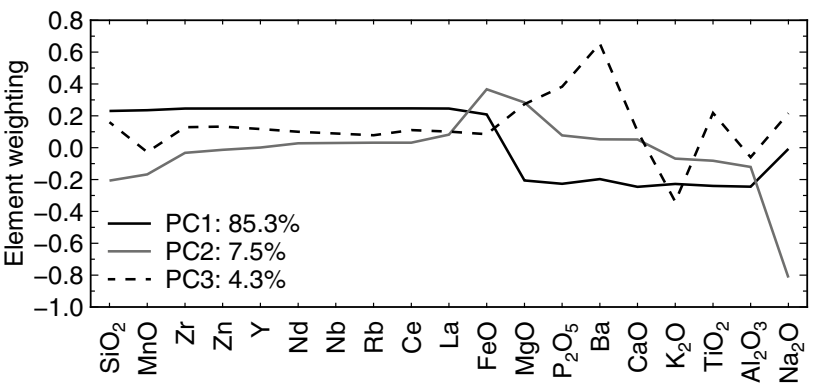

Fig. 11 Elemental weightings for the first three principal components (PC1-PC3) in whole-rock data from the Khaggiar lava flow. Elements that correlate similarly are grouped together as per Supplementary Fig. 4 . The proportion of total variance accounted for by each principal component is shown. Over $97 \%$ of total variance in the Khaggiar lava can be accounted for by three principal components that relate to three distinct magma assembly processes

\section{Matrix glass and whole-rock records of crystallisation, mixing and accumulation}

Mass balance calculations indicate that lava and pumice matrix glass compositions are unlikely to be related by crystallisation along a liquid line of descent. Attempts to reproduce lava matrix glass compositions from pumice matrix glass compositions by the removal of observed macrocryst phases (i.e., alkali feldspar + aenigmatite + clinopyroxene \pm olivine) through least squares modelling returned unacceptably high misfits (RMS $>0.4$ ) and geologically implausible crystallising assemblages dominated by aenigmatite; peralkaline magma evolution is driven primarily by the crystallisation of alkali feldspar not aenigmatite (White et al. 2009; di Carlo et al. 2010). I, therefore, suggest that lava and pumice matrix glass compositions probably reflect distinct magma batches that evolved in isolation along slightly different liquid lines of descent under different conditions. For example, even slight differences in $f_{\mathrm{O}_{2}}$ and magmatic volatile contents (i.e., $a_{\mathrm{H}_{2} \mathrm{O}}$ and $a_{\mathrm{F}}$ ) can result in different residual melt compositions by changing the compositions and proportions of alkali feldspar, clinopyroxene, aenigmatite, olivine and $\mathrm{Fe}-\mathrm{Ti}$ oxides in crystallising assemblages (Scaillet and Macdonald 2001, 2003; di Carlo et al. 2010; Macdonald et al. 2011). Differences in pressure can also affect relative degrees of $\mathrm{Na}$ or $\mathrm{K}$ enrichment by changing alkali feldspar-melt equilibria (Tuttle and Bowen 1958; Macdonald et al. 2011), but are unlikely to have been important in the generation of pantescan pantellerites that differentiate within a narrow pressure interval centred at $100 \mathrm{MPa}$ (di Carlo et al. 2010; Gioncada and Landi 2010; Neave et al. 2012; Romano et al. 2018).

Mixing and accumulation trends were calculated to identify the processes responsible for creating chemical variability in matrix glasses and whole-rock samples from the Khaggiar lava flow and Cuddia Randazzo pumice cone.
Three endmembers were used for calculating mixing trends: the mean lava matrix glass composition, the mean pumice matrix glass composition and the new enclave whole-rock composition reported here. Crystal accumulation trends were calculated using mean mineral compositions (lavahosted alkali feldspar, enclave-hosted alkali feldspar and lava-hosted clinopyroxene), the new enclave whole-rock composition reported here and the composition defining variability along the first principal component of whole-rock data from the Khaggiar lava flow.

The composition of the single glass embayment measured within an alkali feldspar in the Khaggiar lava flow can be reproduced by mixing lava and pumice matrix glasses in a 9:11 ratio (Fig. 12, solid light red lines). Differences in BSE intensity within the embayment and around its host macrocryst are consistent with the presence of multiple melt compositions (Supplementary Fig. 1). Sinuous variations in BSE intensity around other lava-hosted macrocrysts also attest to the presence of variable and incompletely mixed melts in the Khaggiar lava flow over lengthscales of $10-100 \mu \mathrm{m}$ at the time of quenching (Fig. 3b). Importantly, the feathery texture and heterogeneous distribution of high-BSE patches implies that they do not represent compositional boundary layers. It thus appears likely that compositionally distinct melts supplying the Khaggiar lava flow and Cuddia Randazzo pumice cone interacted shortly before and possibly during eruption. Comparisons with textures in both natural and experimental systems suggest that compositional heterogeneities as fine as those observed in Khaggiar flow can only be preserved over very short timescales, perhaps on the order of hours (De Campos et al. 2008). Future work characterising compositional heterogeneities within matrix glasses from the Khaggiar lava flow could provide quantitative insights into the timescales over which magma mingling occurred prior to lava flow solidification (Perugini et al. 2003, 2010).

The accumulation of alkali feldspar into the mean lava matrix glass composition from the Khaggiar lava flow can account for the sense of compositional variability in most matrix glasses and whole-rock samples [i.e., $(\mathrm{Na}+\mathrm{K}) / \mathrm{Al}$ correlating positively with $\mathrm{SiO}_{2}$ and $\mathrm{FeO}^{*}$ but negatively with $\mathrm{Al}_{2} \mathrm{O}_{3}$ and $\mathrm{CaO}$; Fig. 12, blue lines]. Indeed, the appreciable Stokes' settling velocity of alkali feldspar crystals in a melt with the mean Khaggiar matrix glass composition and a $\mathrm{H}_{2} \mathrm{O}$ content of 4.0 wt.\% (e.g., Neave et al. 2012) indicates that crystal accumulation (including via crystal mush formation and disaggregation) can concentrate crystals within evolved pantescan magma reservoirs: alkali feldspars with diameters of $1 \mathrm{~mm}$ are estimated to sink at a rate of $\sim 0.35 \mathrm{~m} /$ year assuming a temperature of $750{ }^{\circ} \mathrm{C}$ (see below), a melt viscosity calculated following Giordano et al. (2008), a crystal density of $2.58 \mathrm{~g} / \mathrm{cm}^{3}$ from Deer et al. (2013) and a melt density of $2.49 \mathrm{~g} / \mathrm{cm}^{3}$ calculated using molar volumes from Lange and Carmichael (1990), Lange (1997) and Ochs 
Fig. 12 Results of calculations demonstrating the effects of mixing and accumulation on matrix glass and whole-rock compositions. Mixing trends between the mean lava matrix glass composition and the mean pumice matrix glass composition as well as between the mean pumice matrix glass composition and the new enclave whole-rock composition reported here are shown as light and dark red lines with diagonal and vertical crosses, respectively. Each cross represents a $10 \mathrm{wt} . \%$ increment of mixing. Accumulation trends calculated using mean mineral compositions (lava-hosted alkali feldspar, enclave-hosted alkali feldspar and lava-hosted clinopyroxene), the new enclave whole-rock composition reported here and the composition defining variability along the first principal component of whole-rock data from the Khaggiar lava flow are shown as coloured lines with various solid symbols. Each symbol represents a $10 \mathrm{wt} . \%$ increment of accumulation. Major and trace element data from Figs. 4 and 5 are shown in the background
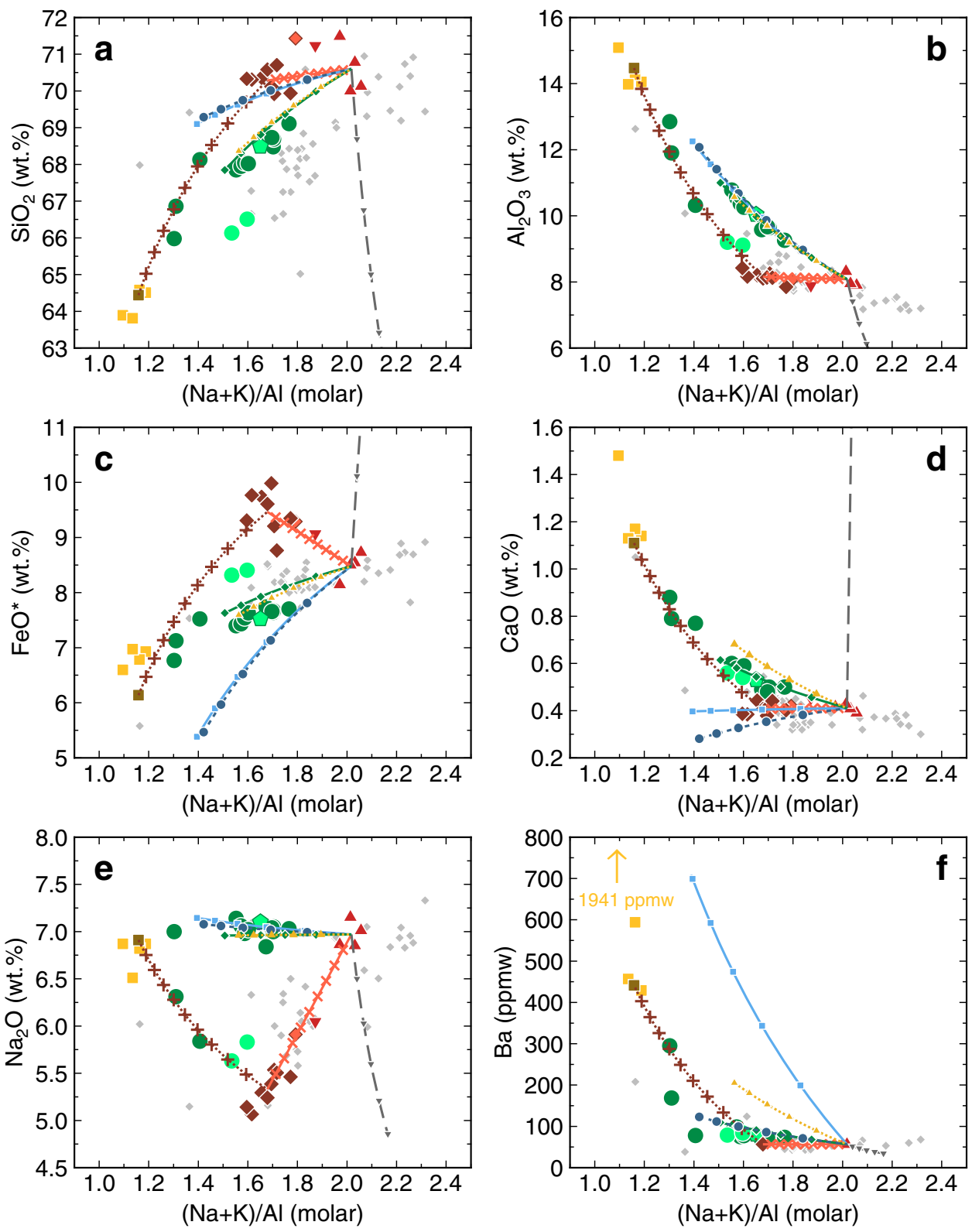

Mixing trends

$*$ lava matrix glass-pumice matrix glass $\cdots+\cdots$ pumice matrix glass-enlcave whole-rock $\longrightarrow$ lava whole-rock PC1
$-\leftarrow$ lava-hosted cpx Accumulation trends
$-\cdots-$ lava-hosted afs
$\ldots$...... enclave whole-rock - enclave-hosted afs and Lange (1997) and thermal expansivities from Bottinga and Weill (1970) and Bottinga et al. (1982). However, the concurrent accumulation of one or more $\mathrm{CaO}-$ and $\mathrm{FeO}^{*}$ rich phases like clinopyroxene alongside alkali feldspar is required to relate matrix glass and whole-rock compositions accurately. Specifically, least squares modelling indicates that variability along the first principal component of whole-rock data from the Khaggiar lava flow is defined by adding an assemblage containing $84 \%$ alkali feldspar, $11 \%$ aenigmatite, $5 \%$ clinopyroxene and negligible olivine, consistent with petrographic observations (Fig. 2). Accumulating 20-50 wt.\% of this assemblage can explain much of the variability in lava whole-rock samples $(85.3 \%$ of total variance; Fig. 11) as well as the difference between lava matrix glass and whole-rock compositions (Fig. 12). Although the proportions of phases defining variability along the first principal component are, aenigmatite aside, broadly similar to those proposed for the crystallising assemblages driving the fractionation of silicic magmas at Pantelleria, (White et al. 2009; Neave et al. 2012), the elevated 
$\mathrm{Al}_{2} \mathrm{O}_{3}, \mathrm{CaO}$ and $\mathrm{Na}_{2} \mathrm{O}$ contents of lava whole-rock samples with respect to literature glass data confirm that variability in whole-rock samples from the Khaggiar lava flow is controlled by crystal accumulation rather than crystal removal (Fig. 12b, c). This is because whole-rock trends are oblique to the liquid line of descent defined by pantescan glasses.

Mixing calculations suggest that the compositions of three modestly peralkaline lava whole-rock samples [i.e., $(\mathrm{Na}+\mathrm{K}) / \mathrm{Al} \sim 1.3-1.4]$ can be accounted for by mixing between enclave whole-rock and mean pumice matrix glass compositions (Fig. 12, dashed dark red lines). Namely, mixing along this trajectory is able to account for the $\mathrm{Na}_{2} \mathrm{O}$-poor but $\mathrm{Ba}$ - and $\mathrm{CaO}$-rich nature of these samples that defines variability along the second principal component of lava whole-rock data; variations in $\mathrm{Na}_{2} \mathrm{O}$ are oblique to the first principal component (Fig. 12e). Two pumice whole-rock compositions reported by Landi and Rotolo (2015) also lie close to this mixing trend, reflecting the incorporation of enclave-derived material into the magmas from which erupted pumices formed.

Lava whole-rock compositions fall either on a trend of macrocryst accumulation into the mean lava matrix glass composition or on a mixing trend between enclave wholerock and mean pumice matrix glass compositions. Thus, while much of the Khaggiar lava flow is highly peralkaline $[(\mathrm{Na}+\mathrm{K}) / \mathrm{Al} \sim 2.0$ in the lava matrix glass], some parts of the flow share a compositional affinity with less peralkaline pumice matrix glasses $[(\mathrm{Na}+\mathrm{K}) / \mathrm{Al} \sim 1.7]$ that are in turn associated with a more primitive, enclave-derived signature $[(\mathrm{Na}+\mathrm{K}) / \mathrm{Al} \sim 1.1-1.2]$. These observations thus corroborate the inference from a single glass embayment that lava and pumice matrix glasses interacted shortly before or during the emplacement of the Khaggiar lava flow.

Literature data from whole-rock enclave samples demonstrate that trachytic enclaves in the Khaggiar lava flow and Cuddia Randazzo pumice cone are compositionally diverse (Landi and Rotolo 2015). Performing mixing calculations using the single new enclave whole-rock composition reported here as a mixing endmember is thus a simplification, albeit one that can still account for much of the observed variability outside the main population of whole-rock data. Although most elements including $\mathrm{SiO}_{2}$, $\mathrm{Al}_{2} \mathrm{O}_{3}, \mathrm{FeO} *, \mathrm{Na}_{2} \mathrm{O}, \mathrm{K}_{2} \mathrm{O}$ and $\mathrm{Zr}$ show little variability beyond analytical precision within the enclaves measured, others including $\mathrm{TiO}_{2}, \mathrm{MnO}, \mathrm{MgO}, \mathrm{CaO}, \mathrm{P}_{2} \mathrm{O}_{5}$ and, in particular, Ba show considerable variability (Figs. 4 and 5, and Supplementary Fig. 3). This variability reflects differences in enclave macrocryst contents: $\mathrm{CaO}$ and $\mathrm{Ba}$ reflect the presence of An-bearing and Ba-rich alkali feldspars (e.g., Figs. $3 \mathrm{f}$ and $7 \mathrm{~b}$ ), $\mathrm{TiO}_{2}$ reflects the presence of ilmenite (Fig. 3f), $\mathrm{MnO}$ and $\mathrm{MgO}$ reflect the presence of relatively high- $\mathrm{Mg} \#$ clinopyroxene and $\mathrm{Tp}$ - and forsterite ( $\mathrm{Fo}$, $\mathrm{Mg}_{2} \mathrm{SiO}_{4}$ )-bearing olivine (Figs. 3f, 8, 10b, c) and $\mathrm{P}_{2} \mathrm{O}_{5}$ reflects the presence of apatite (Fig. 3f). Interestingly, these elements define variability along the third principal component of lava whole-rock data (Fig. 11), suggesting that weak enclave signatures in some lava whole-rock samples are also associated with variability in enclave-derived macrocryst proportions and compositions.

\section{Macrocryst records of magma-magma interactions}

The Khaggiar lava flow hosts multiple macrocryst populations, indicating that lava-hosted macrocrysts formed in multiple magmatic environments. Evolved lava-hosted alkali feldspar macrocrysts (i.e., An-free and Ba-poor macrocrysts; Fig. 6) are inclusion poor while less-evolved lava-hosted alkali feldspar macrocrysts (i.e., An-bearing and Ba-rich macrocrysts; Fig. 6) are often inclusion rich (Fig. 3a). This dichotomy is also reflected in the other phases associated with different alkali feldspar populations: evolved alkali feldspars are typically associated with aenigmatites and evolved clinopyroxenes (aegirine-augites; Figs. 3a and 8c) whereas less-evolved alkali feldspars are associated with less-evolved clinopyroxenes (augites; Fig. 3a) whose compositions approach those observed in enclave-hosted macrocrysts (Figs. 8 and 9). Clinopyroxene inclusions within less-evolved lava-hosted alkali feldspars also have similar, augitic compositions to less-evolved clinopyroxene macrocrysts (Figs. 3c and 8). Similarly, Tp-bearing olivine inclusions within the same lava-hosted alkali feldspars have compositions that approach those of enclave-hosted macrocrysts more closely than those of lava-hosted macrocrysts (Figs. 3b, 10b, c). High-BSE intensity and thus presumably $\mathrm{FeO}^{*}$-rich domains around many less-evolved alkali feldspar macrocrysts suggest that less-evolved lava-hosted macrocrysts (i.e., An-bearing and Ba-rich alkali feldspars, Ae-poor clinopyroxenes and Tp-bearing olivines) crystallised from melts closer in composition to pumice matrix glasses than lava matrix glasses. Similarly, the relatively $\mathrm{FeO}^{*}$-rich composition of a single measured glass embayment demonstrates that melts with a pumice matrix glass affinity were transferred into melts that ultimately formed the lava matrix glass alongside less-evolved macrocrysts (Fig. 4c). The euhedral, faceted nature of many less-evolved, lava-hosted macrocrysts (Fig. 3b) provides independent evidence for coupled melt-macrocryst transfer because it implies that they were in textural and chemical equilibrium with their immediate carrier melts $\left(\mathrm{FeO}^{*}\right.$-rich melt films of pumice matrix glass affinity) at the time of quenching. Observations from macrocrysts, therefore, support evidence from whole-rock data that the Khaggiar lava flow and Cuddia Randazzo pumice cone were fed from a reservoir containing at least two compositionally distinct pantelleritic magmas.

Some evolved lava-hosted macrocrysts (i.e., An-free and Ba-poor alkali feldspars, aenigmatites and Ae-bearing 
clinopyroxenes) have resorbed morphologies; alkali feldspars are often subhedral while aenigmatites and clinopyroxenes are often fully anhedral (Figs. 2b and 3a). Evolved macrocrysts were, therefore, out of textural equilibrium with their carrier melts (lava matrix glasses) at the point of quenching. However, evaluating the exact cause of this disequilibrium is challenging because the effects of pressure-temperature- $f_{\mathrm{O}_{2}}$ variations on the phase relations of evolved peralkaline magmas remain to be fully defined (cf. Scaillet and Macdonald 2001, 2003; di Carlo et al. 2010; Romano et al. 2018). Comparing glass and macrocryst compositions from the Khaggiar lava flow with compositions from other peralkaline systems, both natural and experimental, nevertheless suggests that the evolved macrocryst assemblage could have crystallised from the lava matrix glass composition (Scaillet and Macdonald 2003; White et al. 2005, 2009; di Carlo et al. 2010; Macdonald et al. 2011; Neave et al. 2012). Specifically, experimental data indicate that Or-rich alkali feldspar, aegirine-augite and aenigmatite co-crystallise from peralkaline melts $[(\mathrm{Na}+\mathrm{K}) / \mathrm{Al}>1.5]$ at temperatures close to $700{ }^{\circ} \mathrm{C}$ (di Carlo et al. 2010). It is thus unlikely that macrocryst accumulation resulted in significant chemical disequilibrium. Apparent chemical near-equilibrium between evolved macrocrysts and their carrier melts must, therefore, be reconciled with textural disequilibrium in order to explain how the magmas feeding the Khaggiar lava flow were assembled.

The juxtaposition of evolved macrocrysts of lava matrix glass affinity with less-evolved macrocrysts of pumice matrix glass affinity and trachytic enclaves suggests that magma mingling took place before or during eruption and that it brought thermally distinct magmas into contact with each other (Landi and Rotolo 2015). I thus suggest that the interaction of hot, less-evolved magmas $\left(850-950{ }^{\circ} \mathrm{C}\right.$ in the case of trachytes and $\sim 820^{\circ} \mathrm{C}$ in the case of less-evolved pantellerites; White et al. 2005) with cool, evolved magmas $\left(\leq 750{ }^{\circ} \mathrm{C}\right.$ in the case of evolved pantellerites; White et al. 2005) caused evolved macrocrysts to resorb upon mingling (Fig. 3a). Importantly, the amoeboid form of trachytic enclaves shows that they were hot and fluid (i.e., super-solidus) upon injection, maximising their capacity to transfer heat into their cooler pantelleritic hosts (Landi and Rotolo 2015).

Compositional zoning within both lava- and enclavehosted macrocrysts demonstrates that the magma plumbing system which fed the Khaggiar lava flow and Cuddia Randazzo pumice cone experienced multiple recharge events before the one that ultimately led to eruption. Compositional zoning suggests that some domains of less-evolved lava-hosted macrocrysts may have crystallised from trachytic melts (Figs. 6 and 9). In particular, high-Ba zones (up to $\sim 600 \mathrm{ppmw}$ ) within some lava-hosted alkali feldspars indicate that they crystallised in a magmatic environment containing Ba-rich trachytic melts, at least transiently (Figs. 6b and 7a). This is because Ba partitions so strongly into alkali feldspars during the crystallisation of peralkaline magmas $\left(D_{\mathrm{Ba}} \sim 5.5\right.$ in trachytic magmas; Mahood and Stimac 1990 ) that $\mathrm{Ba}$ is efficiently stripped from residual pantelleritic melts; pantellerites contain insufficient Ba to crystallise Ba-rich alkali feldspars (Fig. 5a; Iddon et al. 2018).

Compositional zoning in enclave-hosted macrocrysts reveals that analogous recharge events also took place in less evolved regions of the plumbing system. Specifically, compositional zoning in some enclave-hosted alkali feldspars suggests that their host magmas must have been recharged by highly Ba-rich melts in order to crystallise macrocrysts with up to 3800 ppmw Ba (Fig. 3e, f and 6b): alkali feldspar Ba contents of $\sim 3800$ ppmw may translate into melt Ba contents of $\sim 700$ ppmw (Mahood and Stimac 1990). These new observations are consistent with previous findings that demonstrated the importance of mingling between mafic (potentially hawaiitic) and evolved (trachytic) magmas in creating diverse enclave textures and compositions in the products of pantescan eruptions (Ferla and Meli 2006). Such magma mingling processes also thought to be responsible for the creation of rare intermediate eruption products on Pantelleria (Romengo et al. 2012). The Ba-rich nature of some enclaves, as well as of pantescan trachytes more

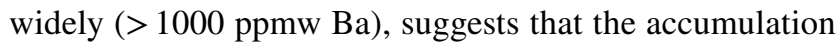
of Ba-rich alkali feldspar (alongside apatite, ilmenite and relatively Mg-rich augite and olivine) exerts a major control over the composition of trachytic magmas on Pantelleria, as reflected by the third principal component of lava wholerock data presented here (Fig. 11; Prosperini et al. 2000; White et al. 2009). Conversely, the relatively low Ba content ( $\leq 400 \mathrm{ppmw}$ ) of some enclave-hosted alkali feldspars suggests that they may have crystallised from Ba-poor melts of pantelleritic affinity and were subsequently transferred into Ba-rich melts of trachytic affinity. Although documenting the full complexity of enclave-hosted macrocrysts is beyond the scope of this study, it would nevertheless appear that trachytic magma bodies beneath Pantelleria are highly dynamic, experiencing recharge by more primitive magmas as well as the accumulation of both relatively more and less evolved macrocrysts. Similar complexity in magma reservoir processes has been identified in the peralkaline eruption products from the Kenya and Main Ethiopian Rifts, where Ba-rich alkali feldspar cargoes are thought to reflect the entrainment of relatively primitive macrocrysts into relatively evolved melts (Macdonald 2012; Iddon et al. 2018). Peralkaline magma reservoirs thus share many characteristics with their calc-alkaline counterparts in which magma mixing, macrocryst entrainment and petrological cannibalism are widespread (e.g., Cashman and Blundy 2013). Similarities may also be drawn with primitive, tholeiitic magma reservoirs, in which macrocrysts often experience multiple 
crystal mush formation and disaggregation events prior to their eventual eruption (e.g., Passmore et al. 2012; Neave et al. 2014).

\section{Pre-eruptive magma assembly}

Chemical variability in matrix glasses and whole-rock samples and their enclave and macrocryst cargoes demonstrates that erupted magmas were assembled from at least three distinct magma types: trachytes, less-evolved pantellerites and evolved pantellerites. Differences in matrix glass compositions imply that less-evolved and evolved pantellerites were stored in discrete melt-rich regions of the pantescan plumbing system (Fig. 13a). Comparisons with other silicic systems suggest that these melt-rich regions were likely nested within a large, crystal-rich magma reservoir (Ellis et al. 2014; Bachmann and Huber 2016). The equilibrium phase assemblage of evolved pantellerites (Or-rich alkali a

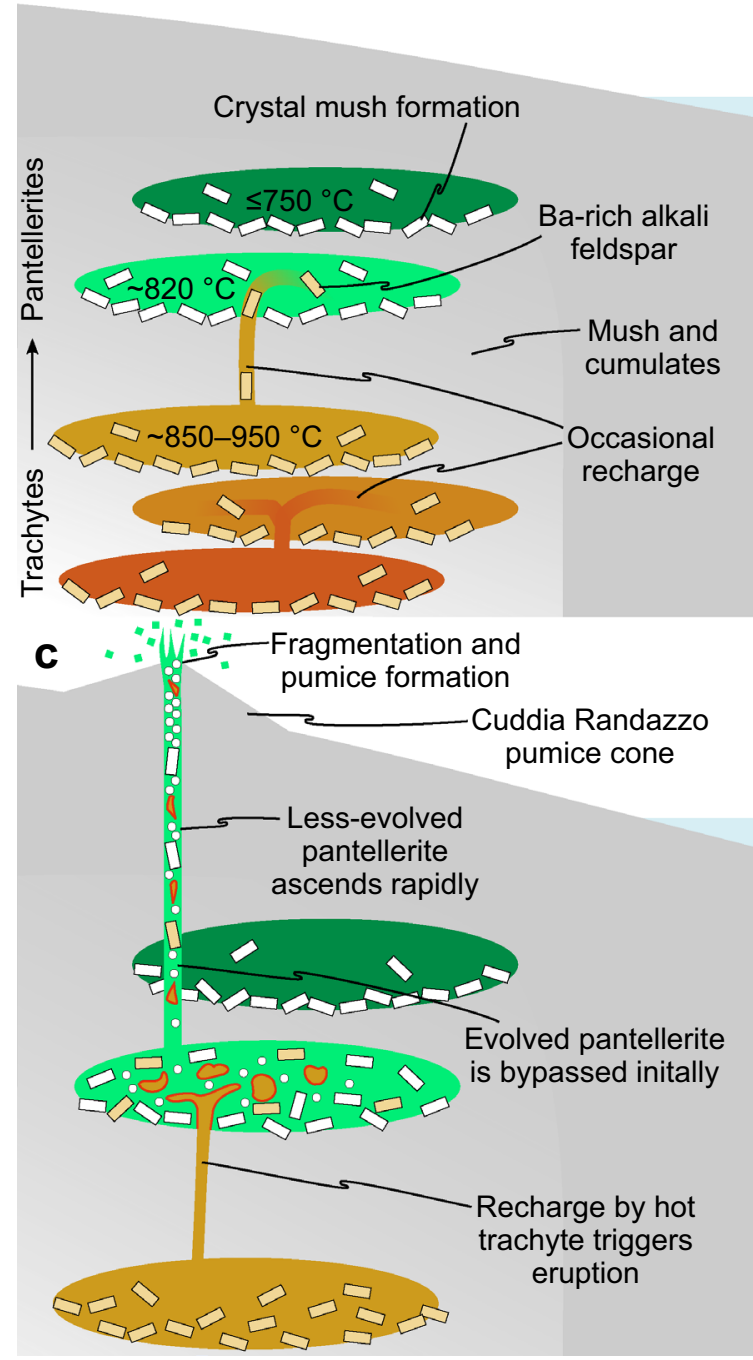

Fig. 13 Cartoon illustrating magma assembly processes in the run up to the emplacement of the Cuddia Randazzo pumice cone and Khaggiar lava flow. a Thermochemically distinct pantelleritic and trachytic magmas evolve in discrete magma bodies within the silicic part of the pantescan magma reservoir. These magma bodies crystallise mushes and are occasionally recharged by injections of less evolved magmas. b A large volume of trachytic magma is injected into a body of less evolved pantellerite. This recharge event transfers heat into the pantelleritic magma and is associated with volatile exsolution. c Heating b

Discrete bodies of evolved (dark) and less-evolved (light) pantellerite
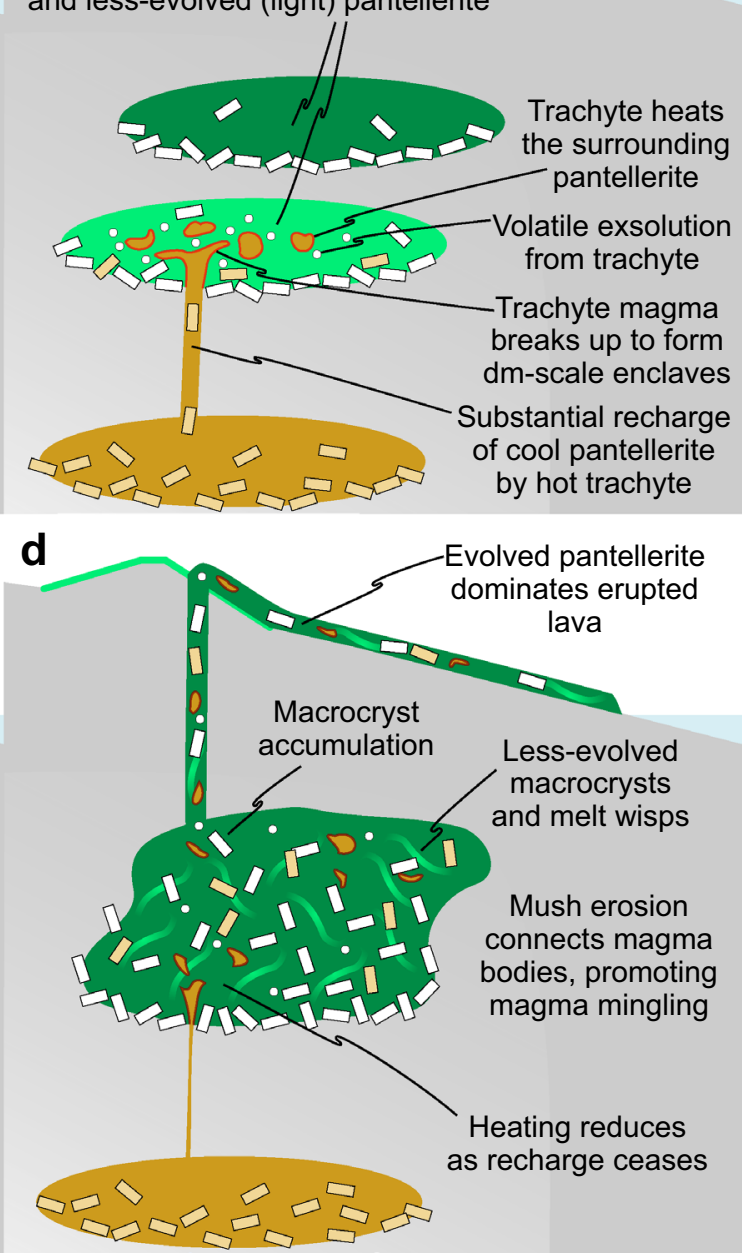

and volatile exsolution trigger the eruption of less evolved pantellerites. These pantellerites ascend sufficiently rapidly to fragment, creating the Cuddia Randazzo pumice cone. d Crystal mush erosion then connects previously discrete magma bodies, resulting in the tapping and eruption of evolved pantellerites to form the Khaggiar lava flow. These evolved pantellerites carry a substantial cargo of accumulated macrocrysts alongside trachytic enclaves and cryptic records of interactions with less evolved pantellerites 
feldspar, aegirine-augite and aenigmatite) indicates that they were stored under relatively cool conditions, most likely at the roof of the plumbing system $\left(\leq 750{ }^{\circ} \mathrm{C}\right.$; White et al. 2005; di Carlo et al. 2010). In contrast, less-evolved pantellerites were stored in hotter and presumably slightly deeper parts of the magmatic system $\left(\sim 820^{\circ} \mathrm{C}\right.$; White et al. 2005). However, the equilibrium phase assemblage of lessevolved pantellerites (mainly An-bearing alkali feldspar and augite) indicates that they were stored at broadly similar pressure to evolved pantellerites $(\sim 100 \mathrm{MPa}$; White et al. 2005; di Carlo et al. 2010). It thus appears likely that the distinct characteristics of the different pantelleritic magmas identified arose from differences in $f_{\mathrm{O}_{2}}$, temperature, melt composition and volatile content rather than significant differences in pressure. Indeed, Romano et al. (2018) estimate that pantescan trachytes also evolved at $\sim 100 \mathrm{MPa}$, implying that the pantelleritic domain of the pantescan magma plumbing system must have been small in volume and limited in vertical extent.

Trachytic enclaves constitute up to 20 vol. \% of the Khaggiar lava flow and Cuddia Randazzo pumice cone, suggesting that the injection of trachytic magmas into pantelleritic magmas probably played a major role in eruption triggering (Mahood and Baker 1986; Prosperini et al. 2000; Landi and Rotolo 2015). The injection of $20 \mathrm{vol} . \%$ hot $\left(850-950{ }^{\circ} \mathrm{C}\right.$; this work; White et al. 2005; Romano et al. 2018) trachytes into cooler pantellerites $\left(\leq 750-820^{\circ} \mathrm{C}\right)$ would have heated the latter considerably (Fig. 13b). Such heating would have reduced magma viscosity, increased convective vigour and ultimately increased magma eruptibility. Importantly, the release of latent heat during enclave crystallisation-trachytic magmas were fluid at the time of injection (Landi and Rotolo 2015) — would have resulted in more sustained heat release than could have been achieved through the dissipation of sensible heat alone. Moreover, the exsolution of volatiles from trachytic enclaves by both decompression and crystallisation-induced second boiling would have further enhanced the ability of a recharge event to trigger an eruption (Landi and Rotolo, 2015). Contrasting the resorbed nature of evolved lava-hosted macrocrysts with the euhedral nature of less-evolved lava-hosted macrocrysts suggests that pre-eruptive temperatures of different pantellerites may have eventually converged towards the liquidus temperature of the pumice matrix glass $\left(\sim 820^{\circ} \mathrm{C}\right.$; Fig. 3a, b). This overall heating of evolved pantellerites would have also helped to facilitate the accumulation of evolved macrocrysts because mushes formed during earlier phases of cooling and crystallisation would have disaggregated through the resorption of grain boundaries and low-temperature interstitial phases (Fig. 13c, d; Burgisser and Bergantz 2011; Cooper and Kent 2014).

The temporal evolution of less-evolved matrix glasses erupted from the Cuddia Randazzo pumice cone into evolved matrix glasses emplaced in the Khaggiar lava flow demonstrates that different magma batches interacted with each other to different degrees during the course of the eruption. Early pumice-forming phases of the eruption were dominated by interactions between trachytes and less-evolved pantellerites, with ascending magmas largely bypassing the evolved pantellerites (Fig. 13c). The magnitudes of volatile exsolution and heat transfer associated with the injection of hot trachytes would have been greatest during the earliest phases of magma-magma interaction when thermal gradients were greatest. This may explain how magma initially ascended fast enough to fragment and create the Cuddia Randazzo pumice cone (Hughes et al. 2017). As the eruption continued, magmas became more evolved and the eruption style became more effusive. This switch may indicate that new magma ascent pathways were opened at depth by mush erosion, as reflected by the accumulation of 20-50 wt.\% macrocrysts into evolved pantellerites (Fig. 13d). The presence of less-evolved macrocrysts within $\mathrm{FeO}^{*}$-rich melt films as well as a partially mixed glass embayment in the Khaggiar lava flow nevertheless demonstrate that some less-evolved pantelleritic material was transferred into the volumetrically dominant evolved pantelleritic magmas, potentially alongside the trachytic enclaves that are found throughout the Khaggiar lava flow.

\section{Conclusions}

Matrix glasses and whole-rock samples from the Khaggiar lava flow and Cuddia Randazzo pumice cone on Pantelleria exhibit significant chemical variability. Lava and pumice samples have different matrix glass compositions, indicating that at least two discrete pantelleritic magmas contributed to the eventual eruption. Although these two magmas are variably peralkaline and can thus be characterised according to their degree of evolution, they cannot be related by crystallisation along a liquid line of descent. Instead, they probably reflect the residual melts of different parental magmas evolving along slightly different liquid lines of descent within largely isolated domains of the pantescan magma reservoir. Pantelleria would, therefore, appear to possess a magma reservoir compartmentalised in a similar way to those in other silicic settings (Ellis et al. 2014; Bachmann and Huber 2016). Combining PCA of whole-rock data with contextualised microanalyses of macrocryst and enclave cargoes reveals that chemical variability in the Khaggiar lava flow was created by at least three distinct processes: the accumulation of an evolved macrocryst assemblage into evolved pantelleritic melts; the injection of trachytic magmas into less-evolved pantelleritic magmas; and the creation of variability within trachytic magmas by the accumulation of more primitive macrocryst cargoes. Magma assembly prior 
to the emplacement of the Khaggiar lava flow and Cuddia Randazzo pumice cone was, therefore, complex in ways that would have been difficult to identify from a single sample. Overlooking intra-eruption chemical variability, especially within the products of small eruptions, may thus result in the development of oversimplified models of magma reservoir architectures and incomplete descriptions of volcanic behaviour.

Trachytic and pantelleritic magma bodies within the pantescan magma reservoir underwent multiple recharge events prior to the one that ultimately triggered eruption. The pantelleritic domains of the reservoir supplying the Khaggiar lava flow and Cuddia Randazzo pumice cone were thus open systems that experienced regular injections of less evolved magmas. Compositional zoning, resorption textures and mineralogical diversity in the macrocryst and enclave cargoes of other pantescan eruptions demonstrate that such open system behaviour is widespread beneath Pantelleria (e.g., Ferla and Meli 2006; Romengo et al. 2012; Liszewska et al. 2018). Similar conclusions have been drawn for peralkaline volcanoes in the Kenya and Main Ethiopian Rifts, albeit from inter-eruption rather than intra-eruption perspectives (Macdonald et al. 2008; Macdonald 2012; Iddon et al. 2018). Peralkaline volcanoes are, therefore, characterised by magma plumbing systems that are equally complex as those beneath calc-alkaline volcanoes (e.g., Hildreth 2004; Cashman et al. 2017; Edmonds et al. 2019). Magma mingling and macrocryst entrainment appear to be ubiquitous in peralkaline magma reservoirs and exert major controls over the petrological diversity of erupted magmas and their crystal cargoes, even if variability in crystal cargoes is not as immediately striking as it is in some calc-alkaline magmas (cf., Streck 2008; Cashman and Blundy 2013). Small peralkaline eruptions like the $<0.1 \mathrm{~km}^{3}$ DRE event investigated here are thus fed from magma reservoirs with similar properties to those that feed much larger events like the $>5 \mathrm{~km}^{3}$ DRE $\sim 45 \mathrm{ka}$ Green Tuff eruption. In other words, magma reservoir complexity does not appear to scale with eruption size, at least in silicic peralkaline systems.

Acknowledgements Thanks to Margaret E. Hartley and Michael J. Stock for providing feedback on an earlier version of this manuscript. Thanks also to Ray Macdonald and one anonymous reviewer for their insightful and constructive comments that improved the manuscript's clarity considerably, as well as to Othmar Müntener for his efficient editorial handling. Many thanks to Agnes F. Upshall, field assistant and knitter in residence, for her help during fieldwork. Fieldwork and XRF analyses were supported by a grant from the Elspeth Matthews Fund of the Geological Society of London. I also acknowledge support from the Alexander von Humboldt Foundation (Postdoctoral Research Fellowship) and the University of Manchester (Presidential Fellowship).

Open Access This article is licensed under a Creative Commons Attribution 4.0 International License, which permits use, sharing, adaptation, distribution and reproduction in any medium or format, as long as you give appropriate credit to the original author(s) and the source, provide a link to the Creative Commons licence, and indicate if changes were made. The images or other third party material in this article are included in the article's Creative Commons licence, unless indicated otherwise in a credit line to the material. If material is not included in the article's Creative Commons licence and your intended use is not permitted by statutory regulation or exceeds the permitted use, you will need to obtain permission directly from the copyright holder. To view a copy of this licence, visit http://creativecommons.org/licenses/by/4.0/.

\section{References}

Allègre CJ, Schiano P, Lewin E (1995) Differences between oceanic basalts by multitrace element ratio topology. Earth Planet Sci Lett 129:1-12

Andersen DJ, Lindsley DH (1988) Internally consistent solution models for Fe-Mg-Mn-Ti oxides: Fe-Ti oxides. Am Miner 73:714-726

Aspinall W, Auker M, Hincks TK, Mahony S, Nadim F, Pooley J, Sparks RSJ, Syre E (2011) Volcano hazard and exposure in GDRFF priority countries and risk mitigation measures-GFDRR Volcano Risk Study. Bristol Univ Cabot Inst NGI Nor World Bank Wash NGI Rep 20100806:1-309

Bachmann O, Huber C (2016) Silicic magma reservoirs in the Earth's crust. Am Miner 101:2377-2404

Bacon CR, Druitt TH (1988) Compositional evolution of the zoned calcalkaline magma chamber of Mount Mazama, Crater Lake, Oregon. Contrib Miner Petrol 98:224-256

Barberi F, Ferrara G, Santacroce R, Treuil M, Varet J (1975) A transitional basalt-pantellerite sequence of fractional crystallization, the boina centre (Afar Rift, Ethiopia). J Petrol 16:22-56

Bottinga Y, Weill DF (1970) Densities of liquid silicate systems calculated from partial molar volumes of oxide components. Am J Sci 269:169-182

Bottinga Y, Weill DF, Richet P (1982) Density calculations for silicate liquids. I. Revised method for aluminosilicate compositions. Geochim Cosmochim Acta 46:909-919

Burgisser A, Bergantz GW (2011) A rapid mechanism to remobilize and homogenize highly crystalline magma bodies. Nature 471:212-215

De Campos CP, Dingwell DB, Perugini D, Civetta L, Fehr TK (2008) Heterogeneities in magma chambers: Insights from the behavior of major and minor elements during mixing experiments with natural alkaline melts. Chem Geol 256:131-145

di Carlo I, Rotolo SG, Scaillet B, Buccheri V, Pichavant M (2010) Phase equilibrium constraints on pre-eruptive conditions of recent felsic explosive volcanism at Pantelleria Island, Italy. J Petrol 51:2245-2276

Cashman KV, Blundy JD (2013) Petrological cannibalism: the chemical and textural consequences of incremental magma body growth. Contrib Miner Petrol 166:703-729

Cashman KV, Sparks RSJ, Blundy JD (2017) Vertically extensive and unstable magmatic systems: a unified view of igneous processes. Science 355:eaag3055

Civetta L, Cornette Y, Crisci GM, Gillot PY, Orsi G, Requejo CS (1984) Geology, geochronology and chemical evolution of the island of Pantelleria. Geol Mag 121:541-668

Civetta L, Cornette Y, Gillot PY, Orsi G (1988) The eruptive history of Pantelleria (Sicily Channel) in the last $50 \mathrm{ka}$. Bull Volcanol 50:47-57

Civetta L, D'Antonio M, Orsi G, Tilton GR (1998) The geochemistry of volcanic rocks from pantelleria island, sicily channel: petrogenesis and characteristics of the mantle source region. J Petrol 39:1453-1491

Civile D, Lodolo E, Tortorici L, Lanzafame G, Brancolini G (2008) Relationships between magmatism and tectonics in a continental 
rift: the Pantelleria Island region (Sicily Channel, Italy). Mar Geol 251:32-46

Clarke B, Calder ES, Dessalegn F, Fontijn K, Naylor M, Butler I, Hutchison W, Yirgu G (2019) Fluidal pyroclasts reveal the intensity of peralkaline rhyolite pumice cone eruptions. Nat Commun 10:2010

Cooper KM, Kent AJR (2014) Rapid remobilization of magmatic crystals kept in cold storage. Nature 506:480-483

Davidson JP, Tepley FJ (1997) Recharge in volcanic systems: evidence from isotope profiles of phenocrysts. Science 275:826-829

Davidson JP, Morgan DM, Charlier BLA, Harlou R, Hora JM (2007) Microsampling and isotopic analysis of igneous rocks: implications for the study of magmatic systems. Ann Rev Earth Planet Sci 35:273-311

Deer W, Howie RA, Zussman J (2013) An introduction to the rockforming minerals. Mineralogical Society, London

Druitt TH, Bacon CR (1989) Petrology of the zoned calcalkaline magma chamber of Mount Mazama, Crater Lake, Oregon. Contrib Miner Petrol 101:245-259

Edmonds M, Cashman KV, Holness M, Jackson M (2019) Architecture and dynamics of magma reservoirs. Philos Trans R Soc A 377:1-29

Ellis BS, Bachmann O, Wolff JA (2014) Cumulate fragments in silicic ignimbrites: the case of the Snake River Plain. Geology 42:431-434

Ferla P, Meli C (2006) Evidence of magma mixing in the "Daly Gap" of alkaline suites: a case study from the enclaves of Pantelleria (Italy). J Petrol 47:1467-1507

Fitton JG, Kilburn CRJ, Thirlwall MF, Hughes DJ (1983) 1982 eruption of Mount Cameroon, West Africa. Nature 306:327-332

Freundt A, Schmincke H-U (1992) Mixing of rhyolite, trachyte and basalt magma erupted from a vertically and laterally zoned reservoir, composite flow P1, Gran Canaria. Contrib Miner Petrol 112:1-19

Di Genova D, Romano C, Hess KU, Vona A, Poe BT, Giordano D, Dingwell DB, Behrens H (2013) The rheology of peralkaline rhyolites from Pantelleria Island. J Volcanol Geoth Res 249:201-216

Gioncada A, Landi P (2010) The pre-eruptive volatile contents of recent basaltic and pantelleritic magmas at Pantelleria (Italy). J Volcanol Geoth Res 189:191-201

Giordano D, Russell JK, Dingwell DB (2008) Viscosity of magmatic liquids: a model. Earth Planet Sci Lett 271:123-134

Gleeson M, Stock M, Pyle D, Tamsin M, Hutchison W, Yirgu G (2017) Constraining magma storage conditions using phase equilibria models at a restless volcano in the main ethiopian rift. J Volcanol Geoth Res 337:44-61

Halldórsson SA, Bali E, Hartley ME, Neave DA, Peate DW, Guðfinnsson GH, Bindeman IN, Whitehouse MJ (2018) Petrology and geochemistry of the 2014-2015 Holuhraun eruption, central Iceland: compositional and mineralogical characteristics, temporal variability and magma storage. Contrib Miner Petrol 173:64

Hildreth W (1981) Gradients in silicic magma chambers: Implications for lithospheric magmatism. J Geophys Res 86:10153-10192

Hildreth W (2004) Volcanological perspectives on Long Valley, Mammoth Mountain, and Mono Craters: several contiguous but discrete systems. J Volcanol Geoth Res 136:169-198

Hughes EC, Neave DA, Dobson KJ, Withers PJ, Edmonds M (2017) How to fragment peralkaline rhyolites: Observations on pumice using combined multi-scale 2D and 3D imaging. J Volcanol Geoth Res 336:179-191

Hutchison W, Pyle DM, Mather TA, Yirgu G, Biggs J, Cohen BE, Barfod D, Lewi E (2016) The eruptive history and magmatic evolution of Aluto volcano: new insights into silicic peralkaline volcanism in the Ethiopian rift. J Volcanol Geoth Res 328:1-82

Iddon F, Jackson C, Hutchison W, Fontijn K, Pyle DM, Mather TA, Yirgu G, Edmonds M (2018) Mixing and crystal scavenging in the Main Ethiopian Rift revealed by trace element systematics in feldspars and glasses. Geochem Geophys Geosyst 20:1-30

Jarosewich E, Nelen JA, Norberg JA (1980) Reference samples for electron microprobe analysis. Geostand Newslett 4:43-47

Jordan NJ, Rotolo SG, Williams R, Speranza F, McIntosh WC, Branney MJ, Scaillet S (2017) Explosive eruptive history of Pantelleria, Italy: repeated caldera collapse and ignimbrite emplacement at a peralkaline volcano. J Volcanol Geoth Res 349:47-73

Landi P, Rotolo SG (2015) Cooling and crystallization recorded in trachytic enclaves hosted in pantelleritic magmas (Pantelleria, Italy): implications for pantellerite petrogenesis. J Volcanol Geoth Res 301:169-179

Lange RA (1997) A revised model for the density and thermal expansivity of $\mathrm{K}_{2} \mathrm{O}-\mathrm{Na}_{2} \mathrm{O}-\mathrm{CaO}-\mathrm{MgO}-\mathrm{Al}_{2} \mathrm{O}_{3}-\mathrm{SiO}_{2}$ liquids from 700 to $1900 \mathrm{~K}$ : extension to crustal magmatic temperatures. Contrib Miner Petrol 130:1-11

Lange RL, Carmichael ISE (1990) Thermodynamic properties of silicate liquids with emphasis on density, thermal expansion and compressibility. Rev Mineral Geochem 24:25-64

Liszewska KM, White JC, Macdonald R, Bagiński B (2018) Compositional and thermodynamic variability in a stratified magma chamber: evidence from the green tuff ignimbrite (Pantelleria, Italy). J Petrol 59:2245-2272

Macdonald R (2012) Evolution of peralkaline silicic complexes: lessons from the extrusive rocks. Lithos 152:11-22

Macdonald R, Belkin HE, Fitton JG, Rogers NW, Nejbert K, Tindle AG, Marshall AS (2008) The roles of fractional crystallization, magma mixing, crystal mush remobilization and volatile-melt interactions in the genesis of a young basalt-peralkaline rhyolite suite, the greater Olkaria volcanic complex, Kenya Rift valley. J Petrol 49:1515-1547

Macdonald R, Bagiński B, Leat PT, White JC, Dzierżanowski P (2011) Mineral stability in peralkaline silicic rocks: Information from trachytes of the Menengai volcano, Kenya. Lithos 125:553-568

Maclennan J, McKenzie D, Hilton F, Grönvold K, Shimizu N (2003) Geochemical variability in a single flow from northern Iceland. J Geophys Res 108:1-21

Magee C et al (2018) Magma plumbing systems: a geophysical perspective. J Petrol 59:1217-1251

Mahood GA (1984) Pyroclastic rocks and calderas associated with strongly peralkaline magmatism. J Geophys Res 89:8540-8552

Mahood GA, Baker DR (1986) Experimental constraints on depths of fractionation of mildly alkalic basalts and associated felsic rocks: Pantelleria, Strait of Sicily. Contrib Miner Petrol 93:251-264

Mahood GA, Hildreth W (1986) Geology of the peralkaline volcano at Pantellaria, Strait of Sicily. Bull Volcanol 48:143-172

Mahood GA, Stimac JA (1990) Trace-element partitioning in pantellerites and trachytes. Geochim Cosmochim Acta 54:2257-2276

Marsh BD (1989) Magma Chambers. Ann Rev Earth Planet Sci $17: 439-474$

Marsh BD (2004) A magmatic mush column Rosetta stone: the McMurdo dry valleys of antarctica. Eos Trans Am Geophys Union $85: 497-508$

Mungall JE, Martin RF (1995) Petrogenesis of basalt-comendite and basalt-pantellerite suites, Terceira, Azores, and some implications for the origin of ocean-island rhyolites. Contrib Miner Petrol 119:43-55

Neave DA, Fabbro GN, Herd RA, Petrone CM, Edmonds M (2012) Melting, differentiation and degassing at the Pantelleria volcano, Italy. J Petrol 53:637-663

Neave DA, Maclennan J, Hartley ME, Edmonds M, Thordarson T (2014) Crystal storage and transfer in basaltic systems: the Skuggafjöll eruption, Iceland. J Petrol 55:2311-2346

Ochs FA, Lange RA (1997) The partial molar volume, thermal expansivity and compressibility of $\mathrm{H}_{2} \mathrm{O}$ in $\mathrm{NaAlSi}_{3} \mathrm{O}_{8}$ liquid: new 
measurements and an internally consistent model. Contrib Miner Petrol 129:155-165

Orsi G, Ruvo L, Scarpati C (1991) The recent explosive volcanism at Pantelleria. Geol Rundsch 80:187-200

Passmore E, Maclennan J, Fitton JG, Thordarson T (2012) Mush disaggregation in basaltic magma chambers: evidence from the $\mathrm{AD}$ 1783 Laki eruption. J Petrol 53:2593-2623

Perugini D, Poli G, Prosperini N (2002) Morphometric analysis of magmatic enclaves: a tool for understanding magma vesiculation and ascent. Lithos 61:225-235

Perugini D, Poli G, Mazzuoli R (2003) Chaotic advection, fractals and diffusion during mixing of magmas: Evidence from lava flows. J Volcanol Geoth Res 124:255-279

Perugini D, Poli G, Petrelli M, De Campos CP, Dingwell DB (2010) Time-scales of recent Phlegrean Fields eruptions inferred from the application of a "diffusive fractionation" model of trace elements. Bull Volcanol 72:431-447

Prosperini N, Perugini D, Poli G, Manetti P (2000) Magmatic enclaves distribution within the Khaggiar lava dome (Pantelleria, Italy): implication for magma chemaber dynamics and eruption. Acta Volcanologica 12:37-47

Rhodes JM (1983) Homogeneity of lava flows: chemical data for historic Mauna Loan eruptions. J Geophys Res 88:A869-A879

Romano P, Andújar J, Scaillet B, Carlo I, Rotolo SG (2018) Phase equilibria of Pantelleria trachytes (Italy): constraints on pre- eruptive conditions and on the metaluminous to peralkaline transition in silicic magmas. J Petrol 59:559-588

Romengo N, Landi P, Rotolo SG (2012) Evidence of basaltic magma intrusions in a trachytic magma chamber at Pantelleria (Italy). Periodico di Mineralogia 81:163-178

Rotolo SG, Castorina F, Cellura D, Pompilio M (2006) Petrology and geochemistry of submarine volcanism in the sicily channel rift. J Geol 114:355-365

Rotolo SG, La Felice S, Mangalaviti A, Landi P (2007) Geology and petrochemistry of the recent $(25 \mathrm{ka})$ silicic volcanism at Pantelleria Island. Bollettino Della Societa Geologica Italiana 126:191-208

Rubin KH, Smith MC, Bergmanis EC, Perfit MR, Sinton JM, Batiza R (2001) Geochemical heterogeneity within mid-ocean ridge lava flows: Insights into eruption, emplacement and global variations in magma generation. Earth Planet Sci Lett 188:349-367

Scaillet B, Macdonald R (2001) Phase relations of peralkaline silicic magmas and petrogenetic implications. J Petrol 42:825-845

Scaillet B, Macdonald R (2003) Experimental constraints on the relationships between peralkaline rhyolites of the Kenya Rift Valley. J Petrol 44:1867-1894

Scaillet B, Macdonald R (2006) Experimental and thermodynamic constraints on the sulphur yield of peralkaline and metaluminous silicic flood eruptions. J Petrol 47:1413-1437

Scaillet S, Rotolo SG, La Felice S, Vita-Scaillet G (2011) High-resolution ${ }^{40} \mathrm{Ar} /{ }^{39} \mathrm{Ar}$ chronostratigrpahhy of the post-caldera (20 ka) volcanic activity at Pantelleria, Sicily Strait. Earth Planet Sci Lett 309:280-290

Sigurdsson H, Sparks RSJ (1981) Petrology of rhyolitic and mixed magma ejecta from the 1875 eruption of Askja, Iceland. J Petrol 22:41-84

Slater L, McKenzie D, Grönvold K, Shimizu N (2001) Melt generation and movement beneath Theistareykir, NE Iceland. J Petrol 42:321-354

Stevenson RJ, Wilson L (1997) Physical volcanology and eruption dynamics of peralkaline agglutinates from Pantelleria. J Volcanol Geoth Res 79:97-122

Streck MJ (2008) Mineral textures and zoning as evidence for open system processes. Rev Mineral Geochem 69:595-622

Thomson A, Maclennan J (2013) The distribution of olivine compositions in icelandic basalts and picrites. J Petrol 54:745-768

Troll VR, Schmincke H-U (2002) Magma mixing and crustal recycling recorded in ternary feldspar from compositionally zoned peralkaline ignimbrite 'A', Gran Canaria, Canary Islands. J Petrol 43:243-270

Tuttle OF, Bowen NL (1958) Origin of granite in the light of experimental studies in the system $\mathrm{NaAlSi}_{3} \mathrm{O}_{8}-\mathrm{KAlSi}_{3} \mathrm{O}_{8}-\mathrm{SiO}_{2}-\mathrm{H}_{2} \mathrm{O}$. Geol Soc Am Mem 74:1-146

Wall F (2014) Rare earth elements. In: Gunn G (ed) Critical metals handbook. Wiley, Oxford, pp 312-339

White JC, Ren M, Parker DF (2005) Variation in mineralogy, temperature, and oxygen fugacity in a suite of strongly peralkaline lavas and tuffs, Pantelleria, Italy. Can Miner 43:1331-1347

White JC, Parker DF, Ren M (2009) The origin of trachyte and pantellerite from Pantelleria, Italy: Insights from major element, trace element, and thermodynamic modelling. J Volcanol Geoth Res 179:33-55

Wilke S, Holtz F, Neave DA, Almeev RR (2017) The effect of anorthite content and water on quartz-feldspar cotectic compositions in the rhyolitic system and implications for geobarometry. J Petrol $58: 789-818$

Williams R, Branney MJ, Barry TL (2013) Temporal and spatial evolution of a waxing then waning catastrophic density current revealed by chemical mapping. Geology 42:107-110

Wörner G, Schmincke H-U (1984) Mineralogical and chemical zonation of the Laacher See tephra. J Petrol 25:805-835

Zhang C, Koepke J, Wang L-X, Wolff PE, Wilke S, Stechern A, Almeev RR, Holtz F (2015) A practical method for accurate measurement of trace level fluorine in $\mathrm{Mg}$ - and $\mathrm{Fe}$-bearing mineral and glass using electron probe microanalysis. Geostand Geoanal Res 40:351-363

Publisher's Note Springer Nature remains neutral with regard to jurisdictional claims in published maps and institutional affiliations. 